\title{
Ativismo digital:
}

\section{uma análise da repercussão de campanhas feministas na internet}

Resumo: Os movimentos sociais, dentre eles o movimento feminista, adotaram a internet como um espaço de debates e disseminação de ideias. O presente artigo tem como objetivo discutir o papel da internet como ferramenta de divulgação de demandas feministas, através da análise de caso das campanhas "Chega de Fiu-fiu" e "Eu não mereço ser estuprada". Também é objetivo deste artigo verificar a repercussão das campanhas citadas através da análise de conteúdo de comentários no Facebook.

Palavras-chave: Ativismo digital; Feminismo; Análise de conteúdo; Facebook.

\section{Activismo digital: un análisis de la repercusión de las campañas feministas en internet}

Resumen: Los movimientos sociales, entre ellos el movimiento feminista, abrazaron la Internet como un espacio para el debate y la difusión de las ideas. Este artículo tiene como objetivo discutir el papel de la Internet como una herramienta de difusión de las demandas feministas a través de un análisis descriptivo de las campañas brasileñas "Chega de Fiu-fiu" y "Eu não mereço ser estuprada". También es objetivo de este artículo verificar el impacto de las campañas citadas a través de análisis de contenido en Facebook.

Palabras-clave: Activismo digital; Feminismo; Análisis de contenido; Facebook.

\section{Digital activism: an analysis of the repercussion of feminist campaigns on the internet}

\begin{abstract}
Social movements, including the feminist movement, have adopted the Internet as a space for debate and dissemination of ideas. This article aims to discuss the role of the internet as a tool to disseminate feminist demands, through the descriptive analysis of the "Chega de Fiu-fiu" and "Eu não mereço ser estuprada" brazilian campaigns. It is also the goal of this
\end{abstract}

Carla Candida Rizzotto ${ }^{1}$ Natasha Meyer ${ }^{2}$ Fernanda Castro de Sousa ${ }^{3}$ ${ }^{1}$ Doutora em Comunicação (Univer-
sidade Tuiuti do Paraná). Professora
do Programa de Pós-Graduação em
Comunicação da Universidade Fede-
ral do Paraná.

${ }^{2}$ Graduada em Comunicação Social
pela Universidade Federal do Paraná.
${ }^{3}$ Estudante de mestrado do Progra-
ma de Pós-Graduação em Ciências da
Comunicação da Universidade Fede-
ral do Amazonas, bolsista CAPES
3 Graduada em Comunicação
Social pela Universidade Federal
do Paraná. 

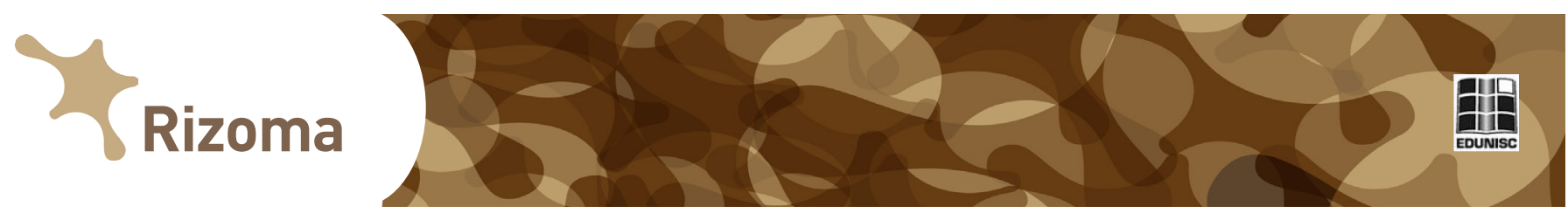

article to verify the repercussion of the cited campaigns through the content analysis of comments on Facebook.

Keywords: Digital ativism; Feminism; Content analysis; Facebook.

\section{Introdução}

Apesar de o machismo estar enraizado na cultura brasileira, as discussões sobre igualdade de gênero têm ganhado cada vez mais destaque. Ainda assim, o tema continua não sendo muito explorado pelos meios de comunicação tradicionais. Diante disso, o feminismo, bem como outros movimentos sociais, adotou a internet como um espaço de debates e disseminação de ideias. Dessa maneira, surgem novas formas de ativismo e de mobilização social, em que as mídias digitais funcionam como ferramenta de engajamento e militância.

A Agência Ideal, junto com o blog Think Olga, realizou um estudo ${ }^{5}$ mostrando que termos como "feminismo" e "empoderamento feminino" tiveram um aumento significativo em buscas no site de pesquisa Google. Em janeiro de 2014, a palavra feminismo teve, em média, 8,1 mil buscas e, em outubro de 2015, subiu para 90,5 mil. Já o termo "empoderamento feminino", no mesmo período, foi pesquisado cerca de 70 vezes e em outubro de 2015 chegou a 3,6 mil buscas.

Tendo em vista este cenário, o presente artigo tem como objetivo contribuir com a discussão acerca do papel da internet como ferramenta de divulgação de demandas feministas, através do estudo de caso de duas campanhas feministas que alcançaram altos níveis de compartilhamento em 2014: a campanha "Chega de Fiu-fiu" e a campanha "Eu não mereço ser estuprada". Também é objetivo deste artigo verificar a repercussão das campanhas citadas através da análise de conteúdo dos comentários de usuários em publicações de fanpages de veículos tradicionais que faziam referência a elas.

\section{Internet e ativismo}

A internet é hoje o principal sistema de informação da sociedade contemporânea, o que modificou as formas de comunicação e de divulgação de informações. A figura de um polo de comunicação com exclusividade sobre as informações e, portanto, incontestável, foi alterada. O ambiente de comunicação passou a ser mais rico e vasto com uma possibilidade de leitura ampliada. Houve uma liberação da emissão (LEMOS, 2003), qualquer um tem a possibilidade de escrever sobre qualquer coisa, se tornando um produtor de conteúdo e um consumidor crítico do que lê. A formação da opinião pública deixa de ser responsabilidade exclusiva dos grandes meios. ${ }^{4}$

Por essa razão, a internet e as redes sociais em geral estão também 

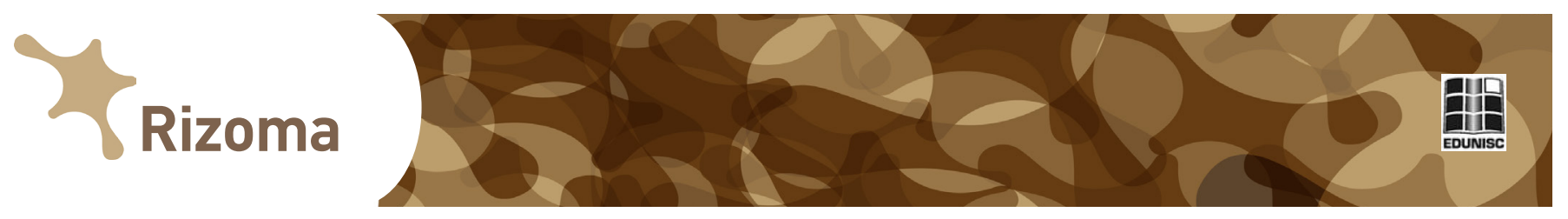

sendo usadas amplamente por ONGs, partidos, sindicatos e movimentos sociais. Isto porque elas proporcionam um ambiente cooperativo, interativo e descentralizado, e trazem a possibilidade de difundir reivindicações. Estes grupos buscam fazer parte do ciberespaço não para atingir milhões de pessoas, e sim para disseminar suas ideias, interagir, criticar, sugerir ou contestar (MORAES, 2000). Este uso diferenciado por parte dos movimentos sociais a projetou como um ambiente de discussão, luta e militância, um fórum on-line no qual as vozes da sociedade civil se somam.

O cenário contemporâneo, de emergência de uma nova cultura política, constitui-se, de um lado, pela construção de modelos democráticos mais participativos e, de outro, por uma profunda mudança no perfil das lutas sociais. A mudança intrínseca nas feições dos novos movimentos sociais provoca modificações no modus operandi dos projetos mobilizadores, gerando um novo tipo de ativismo. A comunicação tem destacado papel neste contexto, seja devido aos processos de visibilidade midiática, seja pela necessidade de compor estratégias de relacionamento com os públicos desses movimentos em torno de suas causas. (HENRIQUES, 2007, p. 92).

Com a crescente urbanização, globalização e com a ampliação da cidadania e do exercício político democrático, novos movimentos sociais estão surgindo, com uma luta mais forte e consistente. Junto com os novos movimentos sociais, está surgindo um novo modelo de ativismo. Ele consiste em incorporar o que estava excluído da participação e da vida política, ampliar a representatividade social a partir de movimentos policêntricos e pluralísticos, formar novas alianças, combinar uma gama de atividades com as propostas transformadoras dos movimentos e agir em redes de solidariedade (HENRIQUES, 2007).

O processo de transformação dos movimentos sociais e do próprio ativismo tem uma forte relação com o papel desempenhado pela comunicação. Os movimentos têm buscado nas estratégias de comunicação suporte para conquistar legitimidade e adesão. Além disso, de acordo com Henriques (2007), o sistema da mídia e o sistema político possuem uma grande troca de influências e uma estreita ligação entre eles.

Tendo em vista que as ações sociais ainda não possuem uma forte representação na grande mídia, os movimentos sociais se tornam cada vez mais dependentes das ferramentas de comunicação. Por isso, eles precisam se engajar muito mais para mostrar a sua luta, disseminar seu discurso e mobilizar a sociedade. As redes sociais e a Internet como um todo, sendo meios de comunicação de fácil acesso, baratos e democráticos, abriram as portas para esta relação da comunicação com as formas atuais de ativismo e mobilização social.

Henriques (2007) fala da relação dos movimentos sociais em geral com a comunicação, mas também podemos levar suas análises para um ambiente micro, como por exemplo, para o movimento feminista. O movimento feminista conseguiu ampliar sua mobilização no momento em que passou a alcançar grupos que não possuíam contato físico com as feministas. A potencialização da mobilização veio com a internet e com as 

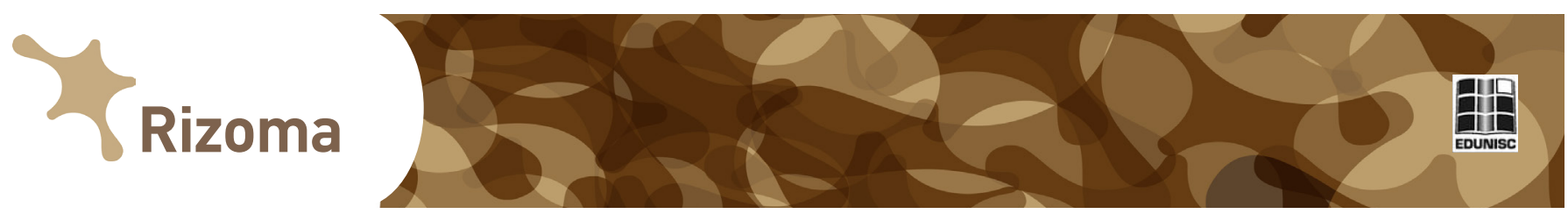

estratégias comunicativas aderidas pelo movimento. Henriques (2007) ainda afirma que os movimentos sociais começaram a se preocupar mais com a questão comunicacional, pois a mídia gera visibilidade e dá mais chances de os movimentos colocarem suas lutas em pauta na sociedade, gerando um debate público em torno do problema.

A visibilidade conquistada pela exposição na mídia é um "recurso essencial para validar os próprios movimentos como atores importantes na cena política, mostrar força ante os outros atores mais poderosos (como o governo) e desafiar a visão corrente do establishment sobre os mais diversos problemas" (HENRIQUES, 2007, p. 100).

Neste novo modelo de ativismo destacam-se os circuitos comunicativos inovadores:

\begin{abstract}
$\mathrm{Na}$ comunicação dos movimentos sociais ou de projetos mobilizadores, uma questão central é que as estratégias são requeridas especialmente para dirigir aos públicos apelos que possam convencê-los de que uma causa existe em função de um problema concreto, de que ele deve interessar a todos e é passível de transformação. (HENRIQUES, 2007, p. 103).
\end{abstract}

Soma-se a isso a democratização da internet, que possibilita que qualquer um produza conteúdo sem a censura vista nos meios tradicionais, de forma barata, com "abrangência global; velocidade de transmissão; autonomia frente às diretivas ideológicas e mercadológicas dos impérios de comunicação" (MORAES, 2000, p. 145).

\begin{abstract}
As ferramentas da Web podem propiciar aos movimentos sociais uma intervenção ágil em assuntos específicos, acentuando-lhes a visibilidade pública. Outro fator positivo é a constituição de comunidades virtuais por afinidades eletivas. Formam-se, assim, coletivos em rede, por aproximações temáticas, anseios e práticas comuns de cidadania. Eles compartilham ações sociopolíticas, tendo em vista o fortalecimento dos laços comunitários e de uma ética por interações, assentada em princípios de diálogo, de cooperação e de participação. (MORAES, 2000, p.154).
\end{abstract}

Dessa maneira, surgem novas formas de ativismo e de mobilização social, baseadas nessas novas estruturas tecnológicas (PEREIRA, 2011). Esse tipo de ativismo pode se desenvolver tendo a internet apenas como apoio para fortalecer ações externas, como, por exemplo, os convites para eventos nas redes sociais para uma manifestação presencial. Mas também pode ambientar toda sua ação de maneira online, fazendo com que a manifestação ocorra somente no meio virtual, ainda que não se restrinja somente a ele e procure levar o debate para outros âmbitos para que haja uma mudança comportamental.

\title{
2.1 Feminismo e comunicação online
}

Desde sua origem, o movimento feminista encontra dificuldades para difundir suas ideias e conceitos, uma vez que o assunto é dificilmente pautado nas grandes mídias de massa. Com a popularização das novas 

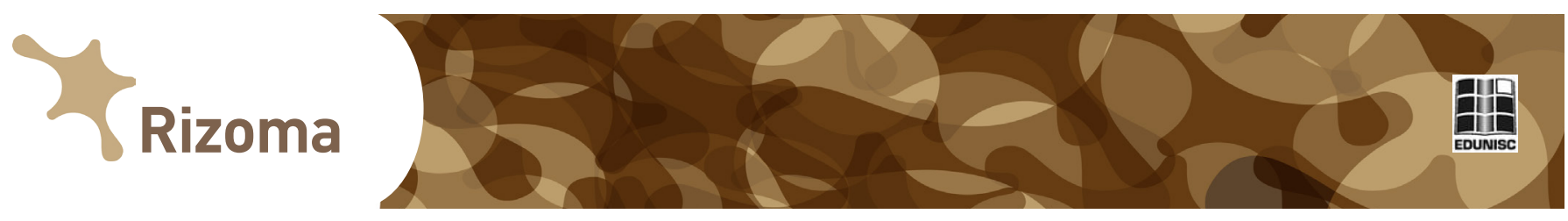

tecnologias de informação e comunicação (TICs), o feminismo - bem como outros movimentos sociais - encontrou um novo espaço para divulgação de seus ideais. A internet e as redes sociais digitais passaram a funcionar como um espaço de intercâmbio de ideias e debates, e como uma ferramenta de engajamento e militância.

Em 2011, quando ocorreu a primeira Marcha das Vadias no Brasil, a imprensa voltou sua atenção para assuntos como machismo e assédio sexual, os quais, até então, eram pouco discutidos. Desde então, blogs com temáticas feministas se popularizaram na rede e passaram a dar mais força ao movimento. Tais blogs passaram a ter grande repercussão quando os ativistas perceberam a internet como um novo instrumento de expressão.

É próprio do feminismo esse compartilhamento de ideias. Apenas o instrumento que mudou, e as mulheres mais jovens foram as protagonistas dessa mudança. Nas décadas anteriores isso era feito por meio de grupos de apoio, mas a internet propiciou não só que esses relatos fossem distribuídos de forma mais ampla, mas reforçou as características de cada mulher. (PARAIZO, 2015, s/p).

Os blogs se propuseram como fontes alternativas de informações que normalmente são esquecidas pela imprensa tradicional e vão desde publicações independentes, como o de Lola Aronovich (Escreva, Lola, Escreva) ${ }^{5}$, a blogs ligados a um grande veículo, como o de Nana Queiroz, no Brasil Post ${ }^{6}$. Segundo as blogueiras, a mulher que aparece nas publicações tradicionais não representa uma mulher real, por isso surge a necessidade de criar uma mídia alternativa que dê voz às mulheres e lhes apresente um conteúdo mais crítico.

"Feministe" e "Feministing", criados em 2001, são alguns exemplos de blogs considerados referência quando o assunto é feminismo. No Brasil, o fenômeno de blogs feministas chegou um pouco mais tarde. $\mathrm{O}$ "Escreva, Lola, Escreva", considerado o blog com maior visibilidade do país, por exemplo, foi criado em janeiro de 2008.

Outra ferramenta de comunicação on-line que tem gerado bastante repercussão são as páginas do Facebook. Com mais de 450 mil curtidas, a página "Moça, você é Machista" "é a maior fanpage feminista do país. As postagens, sempre voltadas para a luta pela igualdade de gênero, abordam temas como aborto, violência doméstica e assédio sexual, além de incorporar a temática LGBTTT.

Uma pesquisa realizada pela jornalista Vera Vieira, na Escola de Comunicações e Artes (ECA) da USP, concluiu que o uso das TICs nas lutas feministas melhora o alcance dos conteúdos de conscientização sobre os temas do movimento. Outro resultado foi que as TICs estreitam os laços entre os diversos grupos feministas do mundo, ampliando a luta e aumentando o engajamento nos debates. Segundo a pesquisadora, as novas dinâmicas comunicacionais da era digital potencializam o movimento feminista e proporcionam um avanço da luta, uma vez que as tecnologias tornam possível uma reconfiguração da identidade e do papel da mulher na sociedade, bem como mudanças na mentalidade (VIEIRA, 2012).

Na era digital, a comunicação a distância mostra-se como um caminho de
${ }^{5}$ Blog da Nana Queiroz no Brasil Post www.brasilpost.com.br/

6 "Escreva, Lola, Escreva" www. escrevalolaescreva.blogspot.com.br/

7 "Feministe": www.feministe.us e "Feministing": www.feministing.com

8 "Moça, você é machista": www. facebook.com/MocaVoceEMachista 


\section{Yizoma}

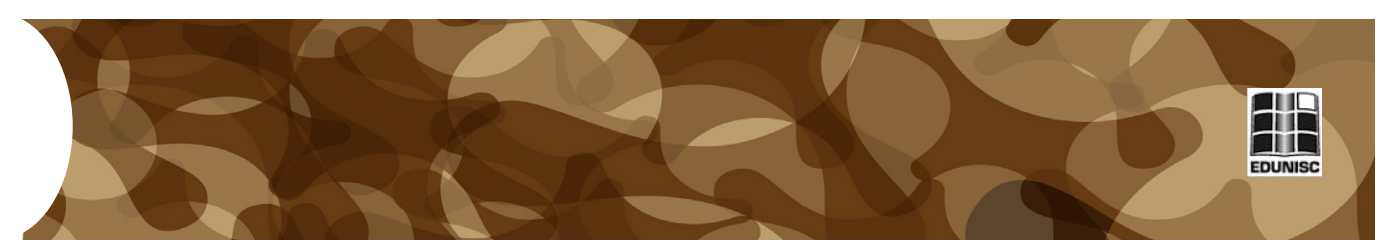

reformulação da agenda feminista, balizada por novas estratégias de intervenção política e de atuação, levando em conta outras dinâmicas e a revolução das formas e expressão pessoal e interpessoal (VIEIRA, 2012, p. 12).

Dessa maneira, os espaços on-line se tornam espaços seguros, onde é possível desfrutar da liberdade de expressão e da privacidade da comunicação. Os relatos digitais se tornam instrumentos que contribuem para a superação pessoal e coletiva, já que a troca de experiências proporciona um reconhecimento público da dor e um aumento de informações que ajudam na superação. As redes têm o poder de aumentar a conscientização e de gerar movimento na opinião pública (VIEIRA, 2012).

Vieira (2012) explica que a utilização da internet nas lutas relacionadas à igualdade de gênero tem pontos negativos e positivos, e podem funcionar tanto para fortalecer o movimento quanto para aprofundar as relações desiguais de poder. Dependendo, assim, de um planejamento estratégico para funcionar a favor do movimento. Dentre os aspectos positivos estão o fluxo ilimitado de informação e conhecimento, a interatividade, a possibilidade de produzir informação. Já os aspectos negativos abrangem o perigo à privacidade, a inclusão de informações não confiáveis, a exclusão digital e o distanciamento nas relações pessoais.

A pesquisa aponta para uma possibilidade concreta de aumento dos temas da agenda feminista no Brasil devido às tecnologias de informação e comunicação, graças à pluralização da informação e à horizontalidade do aprendizado. Uma inovação do estudo foi a constatação de que a inclusão de homens nos processos de capacitação e luta do feminismo são importantes (VIEIRA, 2012).

\section{Campanhas feministas na internet: "Chega de Fiu-fiu" e "Eu não mereço ser estuprada"}

Após uma pesquisa realizada em agosto de 2013 pela jornalista Karin Hueck, foi lançada a campanha "Chega de Fiu-fiu" no blog Think Olga - um espaço virtual para discutir questões feministas - pela jornalista Juliana de Faria Kenski. A pesquisa feita com quase 8 mil mulheres revelou que $99,6 \%$ já passaram por situações constrangedoras nas ruas. De acordo com a pesquisa, muitas mulheres já se conformaram em escutar coisas desagradáveis nas ruas, por ser algo tão rotineiro, mesmo encarando as cantadas como uma ofensa ou humilhação. Apenas 17\% das entrevistadas afirmam gostar das cantadas. O levantamento aponta ainda que $85 \%$ das mulheres já foram tocadas ao andarem sozinhas, e apenas $27 \%$ reagem às cantadas por medo de apanhar; das que reagiram, $37 \%$ foram agredidas. A pesquisa ainda mostrou que $51 \%$ das mulheres sentem medo ao sair nas ruas, e a maioria prefere mudar de caminho, evitar sair de casa em alguns horários, deixar de ir em alguns locais e mudar de roupa para sair nas ruas.

Sendo assim, a campanha foi criada com o intuito de lutar contra o 


\section{Tizoma}

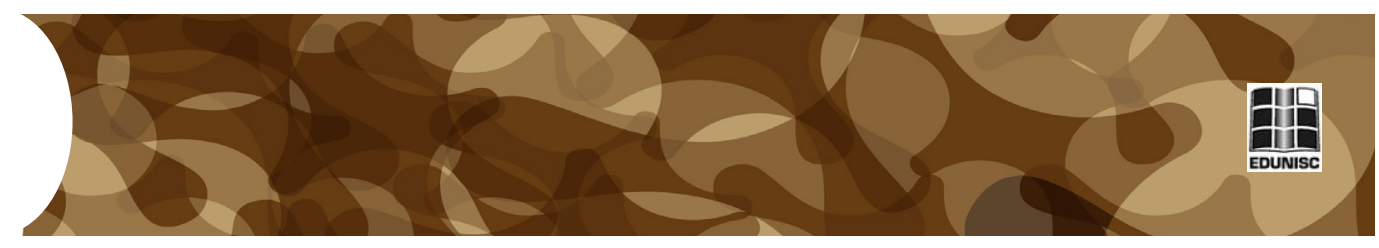

assédio sexual em espaços públicos. Como meio de comunicação, é utilizado o blog Think Olga, que possui uma área exclusiva para apresentar a campanha e mostrar o resultado da pesquisa realizada. O blog ainda disponibiliza um e-mail para que sejam enviadas histórias, opiniões e experiências que são publicadas na seção de depoimentos.

Recentemente, foi criado também um site exclusivo da campanha. No site www.chegadefiufiu.com.br o usuário pode denunciar algo que viu ou que vivenciou. Basta selecionar o tipo de assédio, a cidade na qual ocorreu e descrever o ocorrido. Também podem ser fornecidas informações como: data do assédio, renda, idade, nome, período em que ocorreu o assédio, escolaridade, cor e e-mail. O usuário também pode usar a ferramenta só para saber dos casos relatados, basta selecionar uma cidade e então aparece um mapa com os pontos onde os assédios aconteceram, quando posicionado o mouse em cima do ponto as descrições fornecidas pela vítima aparecem.

O site tem funcionado como uma ferramenta de comunicação pública, e tem auxiliado a quantificar, mapear e categorizar os casos de assédio nas cidades brasileiras. Também funciona como uma forma de mostrar os lugares mais críticos de violência contra mulheres no Brasil. A campanha visava a fomentar discussões que poderiam ajudar os homens a refletirem sobre sua postura e a mudarem seus comportamentos; bem como conscientizar as mulheres sobre os seus direitos, incentivando-as a tomar posse de seus direitos e a se unirem para combater a violência.

A campanha "Eu não mereço ser estuprada" teve início, no Facebook, em março de 2013, através de uma postagem da jornalista Nana Queiroz. A ação surgiu em resposta à divulgação de uma pesquisa realizada pelo Ipea (Instituto de Pesquisa Econômica Aplicada), que informava que 65\% dos entrevistados haviam concordado com a afirmação de que mulheres que usam roupas que mostram o corpo merecem ser estupradas.

No levantamento, que coletou respostas de 3.810 brasileiros durante os meses de maio e junho de 2013 , cerca de $58 \%$ das pessoas afirmaram que "se as mulheres soubessem como se comportar, haveria menos estupros". Desses entrevistados, $66,5 \%$ eram mulheres.

Em protesto, Nana Queiroz tirou uma foto em frente ao Congresso Nacional, DF, tampando os seus seios nus. Nos braços estava escrita a frase: "eu não mereço ser estuprada". A jornalista divulgou a foto na rede social e criou um evento da campanha no dia 27 de março de 2013 convidando as mulheres a publicarem suas fotos acompanhadas da frase "eu não mereço ser estuprada". Na semana seguinte o evento já possuía mais de 44 mil adesões. Mulheres do Brasil inteiro tiraram fotos com a frase, homens também aderiram à campanha e postaram fotos com frases contra estupro nas redes sociais, artistas como Valesca Popozuda, Nana Gouvêa, Geisy Arruda, Juliana Paes, Claudia Leitte e Daniela Mercury também se mobilizaram. 

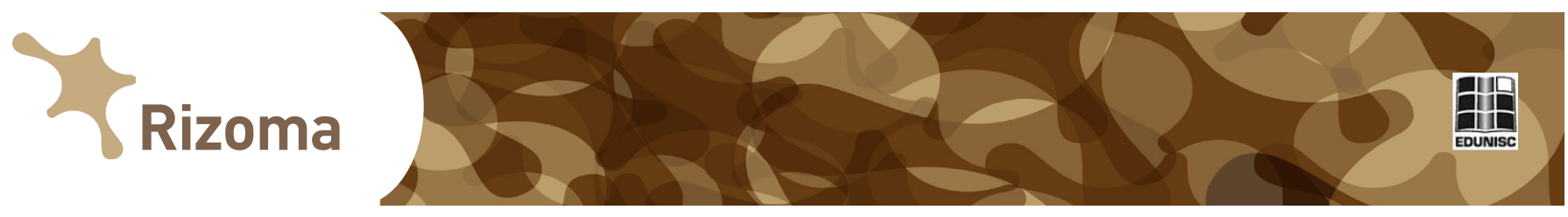

Figura 1: Foto de |Nana Queiroz

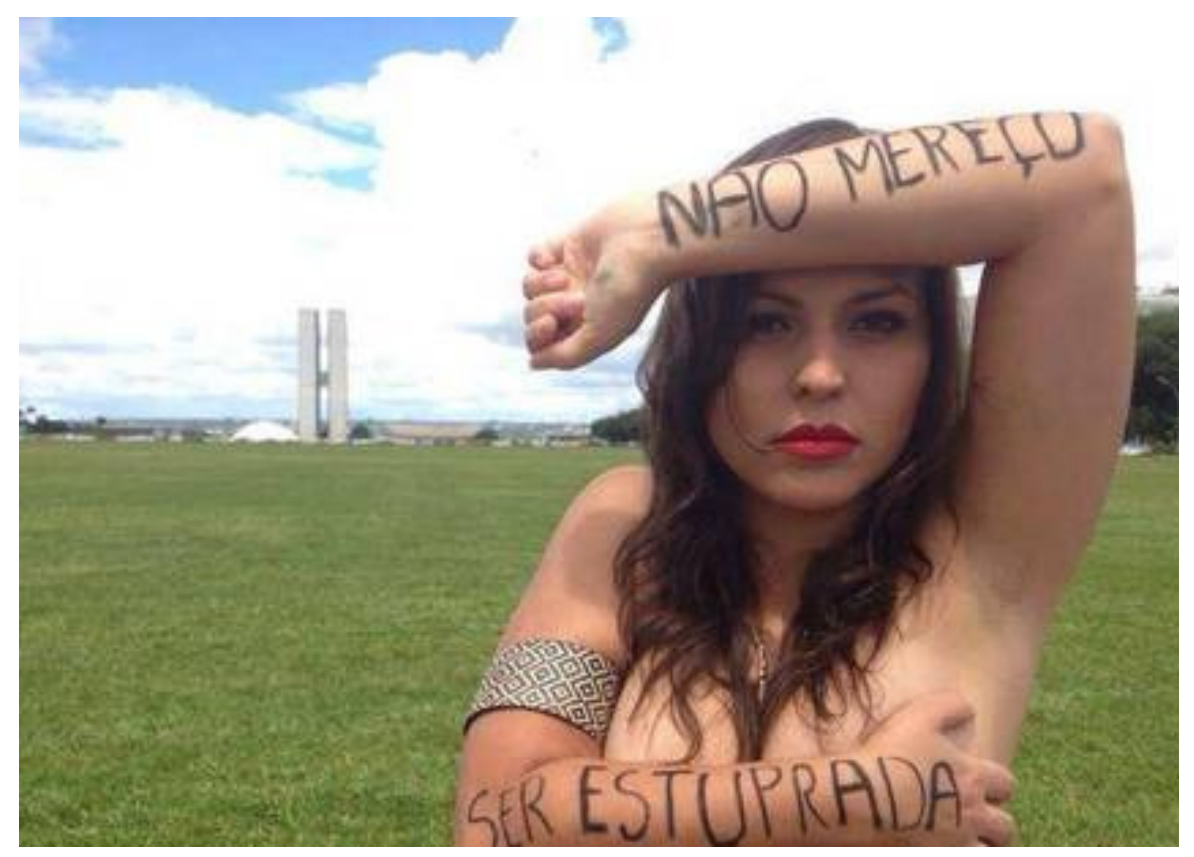

Fonte: Reprodução do Facebook de Nana Queiroz (2015)

Nana Queiroz afirmou que a campanha se mostrou bastante eficiente para mudar a cultura de que a mulher é a culpada pelo estupro. O movimento encorajou as mulheres a falarem sobre o abuso que sofreram, a denunciarem seus agressores e a buscarem ajuda. De acordo com Nana, em entrevista à Revista Época ${ }^{6}$, a campanha teve o intuito de dizer às mulheres que a opressão acabou, "não tolerem desrespeito na rua. Falem! Gritem!".

Semanas depois da divulgação da pesquisa, o IPEA informou que ela estava incorreta, e que, na realidade, o índice real era de $26 \%$. Mas, afirmaram que o índice de $58,5 \%$ dos entrevistados que concordaram com a frase "Se as mulheres soubessem como se comportar, haveria menos estupros" estava correto, o que não elimina o machismo enraizado na nossa sociedade.

\section{O que as pessoas dizem sobre as campanhas feministas?}

Com a cibercultura, os movimentos sociais emergem no espaço virtual e criam novas formas de protesto, organização e cooperação (HOLLENBECK; ZINKHAN, 2006 apud ABDALLA; BRAVO, 2011). A internet quebra as noções de espaço e tempo, tornando a presença física dispensável. Assim, as pessoas se veem livres para questionar e expor suas opiniões com liberdade nas redes sociais digitais (ABDALLA; BRAVO, 2011).

Nesse cenário, buscamos compreender a repercussão que as campanhas on-line "Chega de Fiu-Fiu" e "Eu não mereço ser estuprada" tiveram nas redes sociais. Para isso, analisamos o discurso das pessoas, bem como suas motivações e suas interações com outros usuários. Foram ${ }^{6}$ Entrevista disponível em http://epoca.
globo.com/ideias/noticia/2014/04/nem-
-elas-nem-bninguem-mereceb.html 


\section{Yizoma}

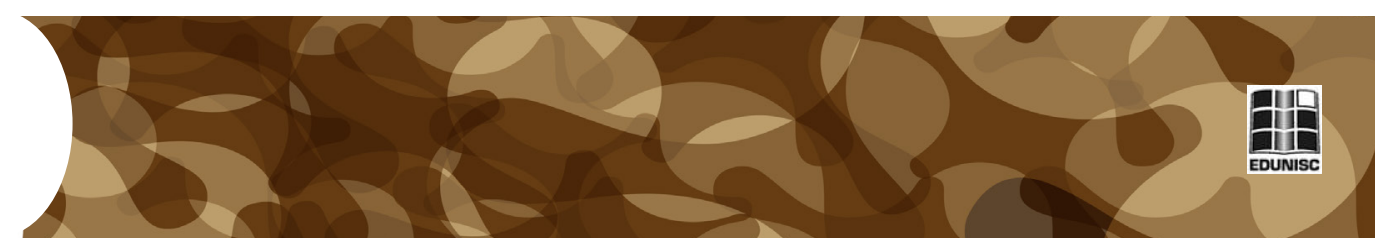

analisadas as primeiras postagens no Facebook sobre as campanhas feitas pelas páginas dos veículos Folha de S. Paulo, Terra e Zero Hora, que têm grande abrangência de público.

Com uma abordagem de pesquisa não participante, foram categorizados os comentários relacionados às campanhas feitos nas postagens do Facebook de cada veículo. Para a seleção, optamos por analisar até 50 comentários mais relevantes da postagem (algumas postagens não atingiram esse número de comentários), que se relacionavam ao tema em questão. Como a quantidade de comentários é pequena, não utilizamos nenhum software específico, mas catalogamos e verificamos todos manualmente.

Os comentários foram categorizados de acordo com o que segue: primeiramente, foram divididos em "racionais" ou "emocionais". Essa classificação é importante pois permite verificar a existência de justificação da opinião, que, de acordo com a Teoria da Ação Comunicativa (HABERMAS, 1984), é evidenciada naquelas asserções que podem ser verificadas empiricamente a partir de evidências. Foram classificadas como racionais os textos que ofereciam justificação, mesmo que baseada na experiência pessoal ou em observações do sujeito. Em segundo lugar os comentários foram classificados em "favoráveis" ou "contrários" à campanha, analisando o conteúdo das mensagens e o que motiva a existência das ideias presentes nelas. Os comentários contrários foram divididos em "crítica ao conteúdo da campanha", "crítica ao movimento feminista", "ameaça a um comentarista" e "ameaça as pessoas da campanha". Os comentários favoráveis foram classificados em "palavras de apoio geral", "relatos pessoais" e "crítica ao conteúdo dos comentários". Foi identificado ainda o gênero dos sujeitos, o que possibilita perceber quem são os autores dos comentários machistas e dos de apoio à campanha, e ainda quem possui mais desconhecimento sobre os temas debatidos pelas campanhas.

\section{1 "Chega de Fiu-fiu" ou "Relaxa, é só um elogio"}

Foram analisados os comentários das postagens sobre a campanha Chega de Fiu-fiu dos seguintes portais de notícias: Terra ${ }^{7}$, Zero Hora $^{8}$ e Folha de S. Paulo 9 . As postagens foram feitas no Facebook entre os dias 08 de março de 2014 e 23 de abril do mesmo ano, período em que surgiu a campanha. A abordagem que cada portal deu à notícia foi diferente. Por isso, é possível notar também uma diferença entre o caráter dos comentários e o nível de entendimento que os internautas tiveram sobre o teor da campanha.

O portal Terra apresentou a campanha Chega de Fiu-fiu e colocou uma imagem retirada do site da campanha. A postagem teve 949 curtidas, 197 compartilhamentos e 61 comentários. Porém, somente 32 estavam relacionados ao conteúdo da postagem. 


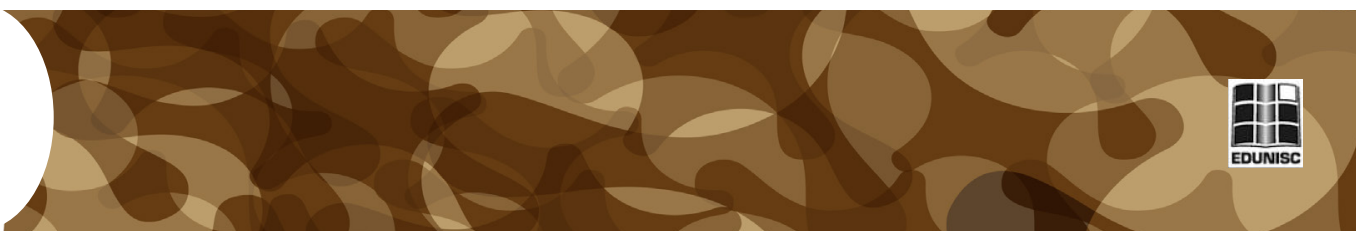

Figura 2: Chega de Fiu-fiu no Terra

\section{Fotos da Linha do Tempo}

Retornar ao álbum - Fotos de Terra - Página de Terra

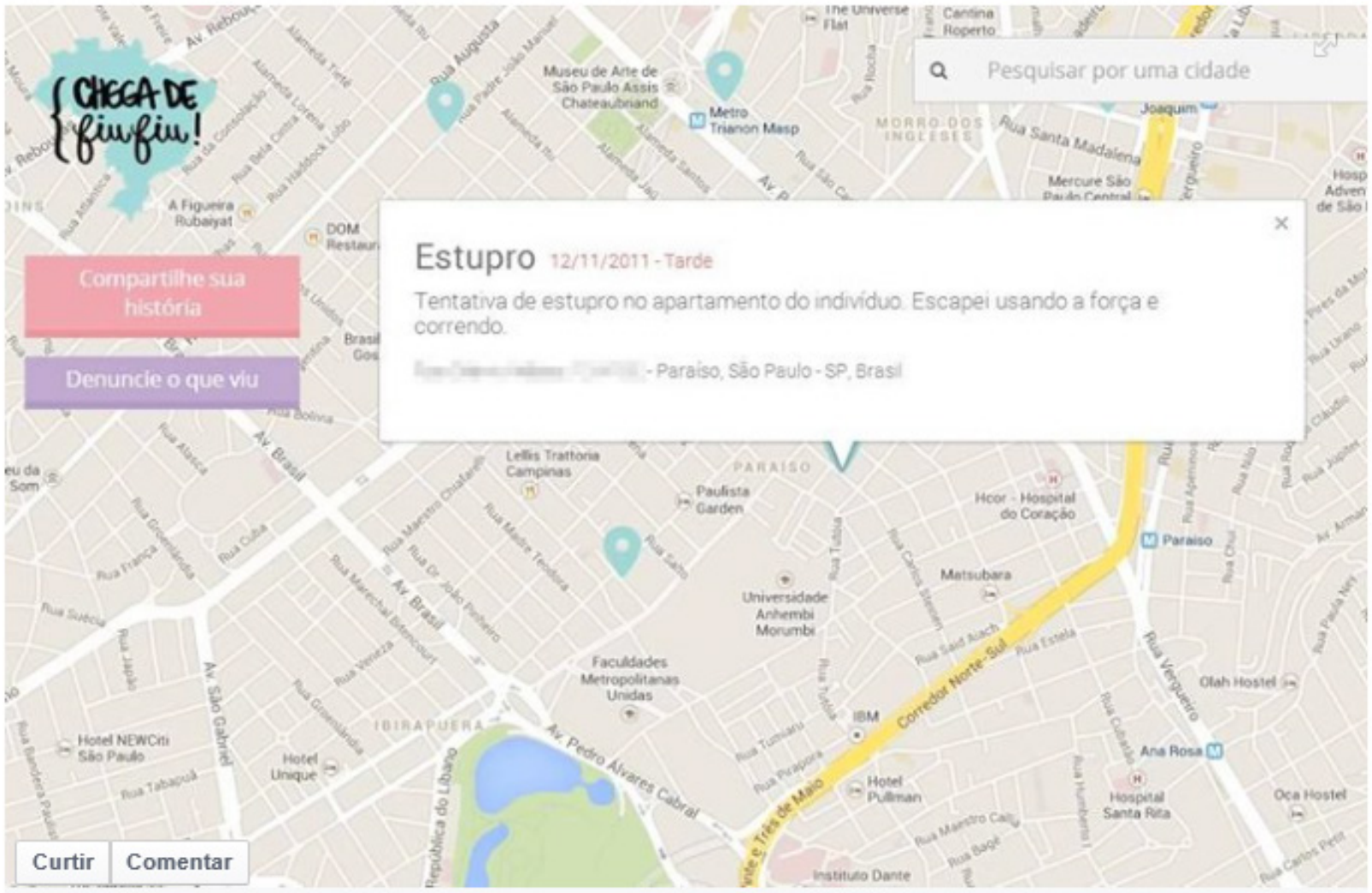

Terra

Chega de Fiu Fiu: site colaborativo mapeia locais onde são registradas ocorrências de assédios sexuais.

Página também registra casos de homofobia ou crimes de ódio: http://bit.ly/1tC2W4P

(Foto: Reprodução)

Curtir - Comentar - Compartilhar - 23 de abril de 2014

B 949 pessoas curtiram isso. Mais relevantes :
A 197 compartilhamentos

Álbum: Fotos da Linha do Tempo

Compartilhado com:

Q Público

Abrir visualizador de fotos

Fazer download

Incorporar publicação

Denunciar foto

Fonte: Reprodução do Facebook de Terra (2015)

A maioria dos comentários provinham de homens que questionavam o que há de errado com o "fiu-fiu". Muitas manifestações eram sarcásticas e menosprezavam a campanha e a luta feminista. Outras reações frequentes eram os que questionavam a validade da campanha, defendendo que ela não conseguiria acabar com a violência e não é a solução para o assédio. Boa parte dos comentários insistiram que existem lutas mais importantes e disseram que as feministas tratam o "fiu-fiu" como se fosse o mesmo que um estupro. Dois comentários foram removidos por serem considerados ofensivos (conforme Figura 3). 

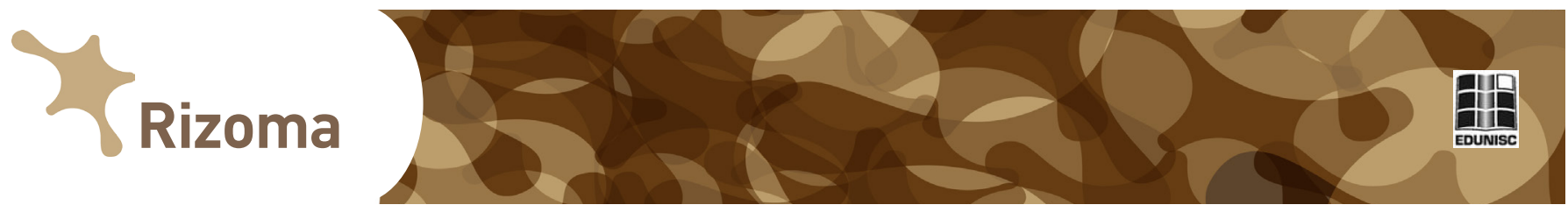

Figura 3: Exemplos ee Comentários (Chega de Fiu-fiu - Terra)

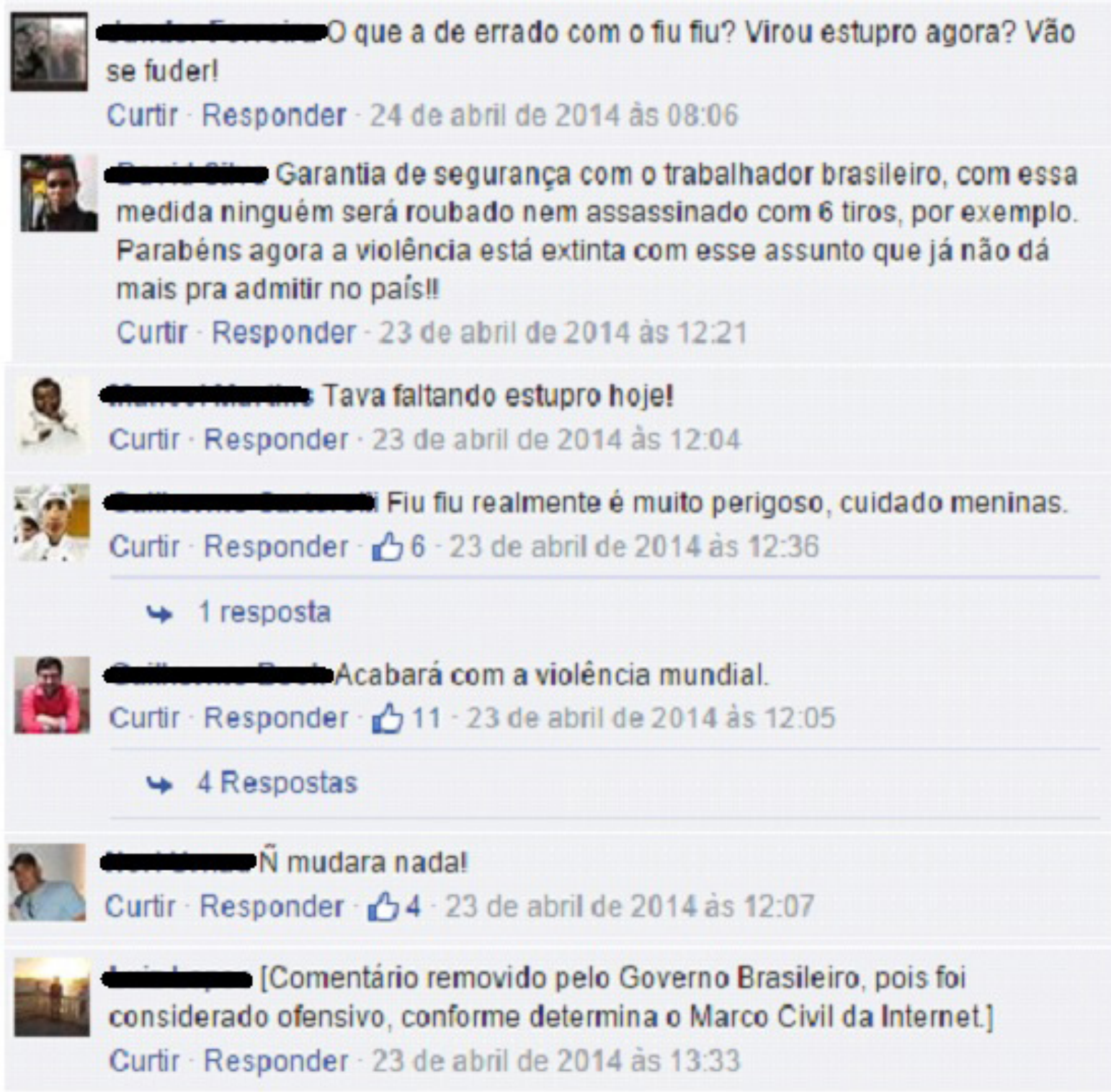

Fonte: Reprodução do Facebook de Terra (2015)

A postagem do Zero Hora (Figura 4) foi feita no Dia Internacional da Mulher, 08 de março, e apresentou a pesquisa feita pela criadora da campanha "Chega de Fiu-fiu", com o intuito de abordar os diversos assédios que a mulher sofre diariamente. A postagem teve 301 curtidas, 74 compartilhamentos e 29 comentários, porém, somente 20 estavam relacionados ao conteúdo da postagem. 

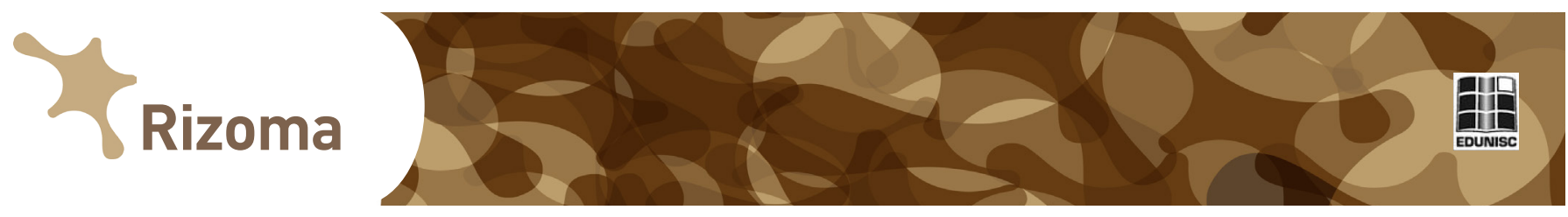

Figura 4: Chega de Fiu-fiu no Zero Hora

Fotos da Linha do Tempo

Retornar ao álbum · Fotos de Zero Hora · Página de Zero Hora

\section{$\overline{\text { ZERO HORA }}$}

\section{Você já deixou de fazer alguma coisa com medo do assédio?}
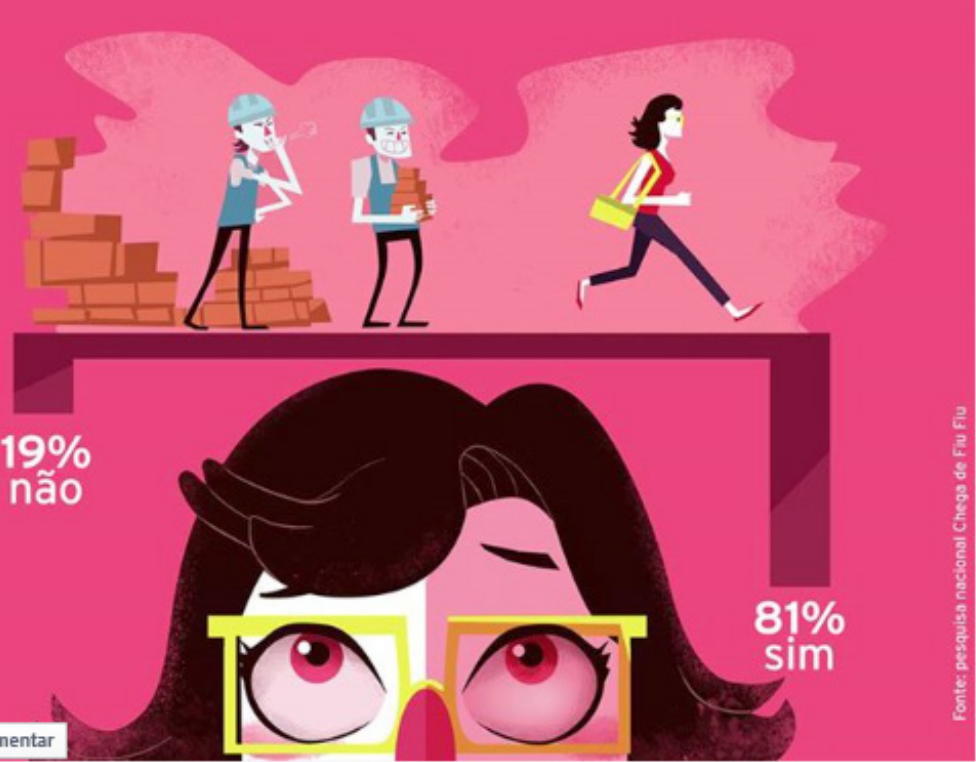

Curtir Comentar

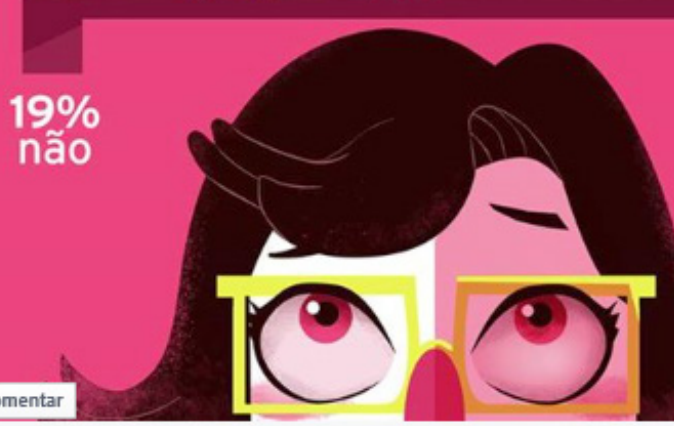

ZH Zero Hora

(1) Muther, vale a reflexân.

Álbum: Fotos da Linha do

Tempo

Pesquisa feita com quase 8 mil mulheres do Brasil inteiro, mostra que elas sofrem vários tipos de assédio diariamente. http:/ithinkolga.com/chega-de-fiu-fiu

Compartilhado com:

A Público

Curtir - Comentar - Compartilhar - 8 de marogo de 2014 - Editado

Abrir visualizador de fotos

301 pessoas curtiram isso.

Mais relevantes

Fazer download

$\Leftrightarrow 74$ compartilhamentos

Incorporar publicaçäo

Fonte: Reprodução do Facebook da Zero Hora (2015)

Nos comentários, houve um maior envolvimento por parte das mulheres. Muitas delas pediam que no Dia Internacional da Mulher fossem presenteadas com mais respeito e menos flores. Foi constante a presença de relatos, mostrando como as mulheres se sentem constrangidas e amedrontadas ao serem assediadas em locais públicos. Apesar disso, indivíduos de ambos os sexos expuseram a ideia de que a mulher assume a culpa por ser assediada/estuprada ao se vestir e se comportar de maneira provocante (conforme Figura 5). 


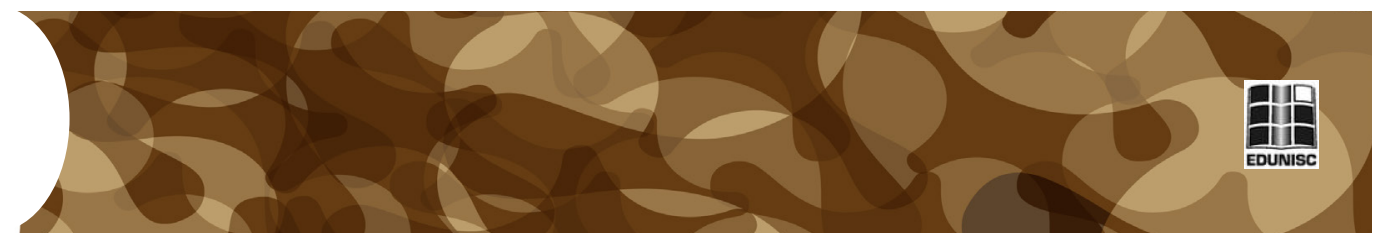

Figura 5: Exemplos de Comentários (Chega de Fiu-fiu - Zero Hora)

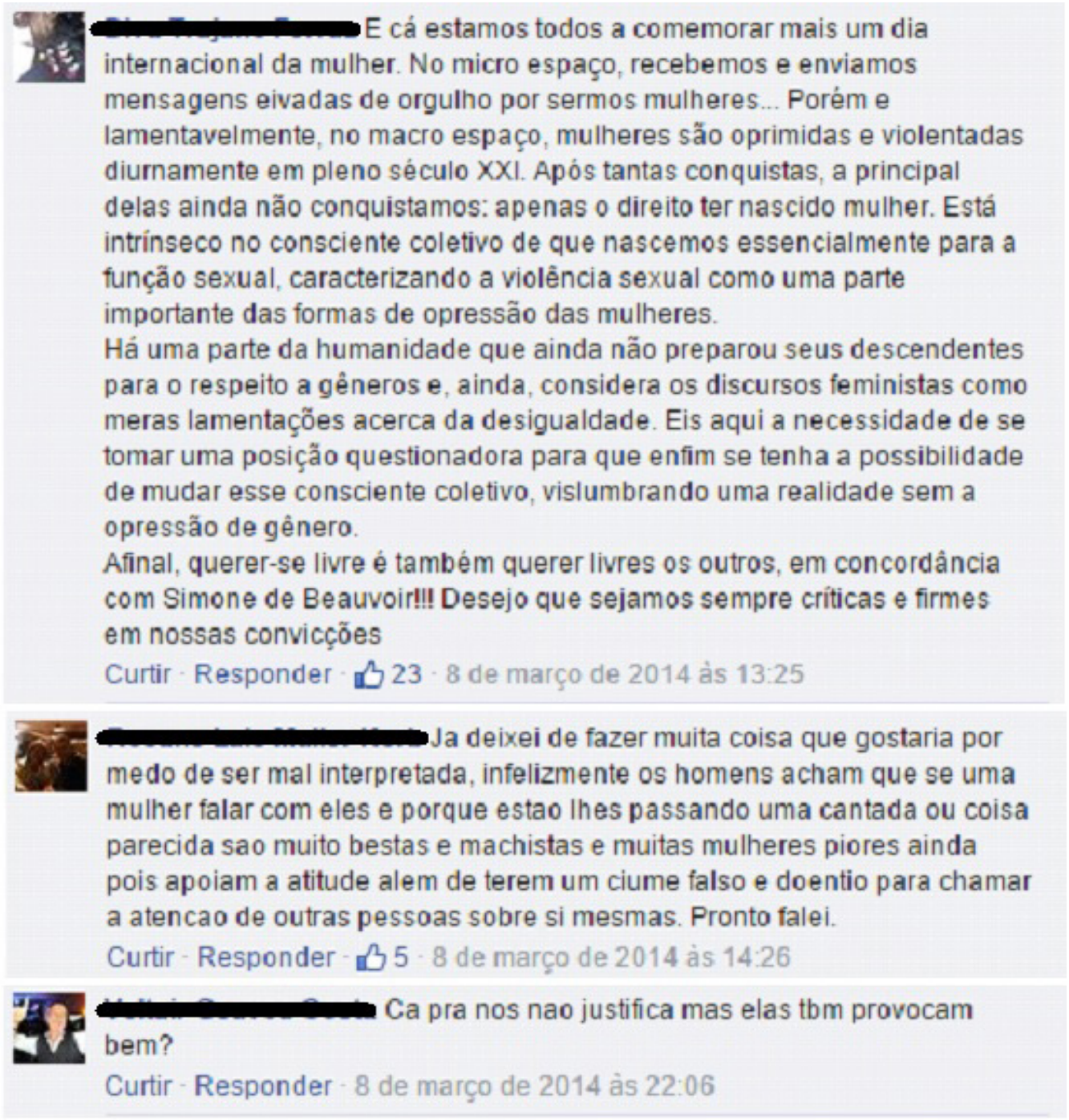

Fonte: Reprodução do Facebook da Zero Hora (2015)

A postagem da Folha de S. Paulo (Figura 6) não fala sobre a campanha diretamente, apesar de apresentar um link que redireciona os internautas a uma notícia em que apresenta o "Chega de Fiu-fiu" e a pesquisa realizada pela campanha. A postagem conta que mulheres estão se unindo contra as cantadas de rua e estão buscando entender o feminismo. A publicação teve 4.381 curtidas, 643 compartilhamentos e 727 comentários, porém, como o número de comentários é grande, analisamos os 50 mais relevantes de acordo com o Facebook. 

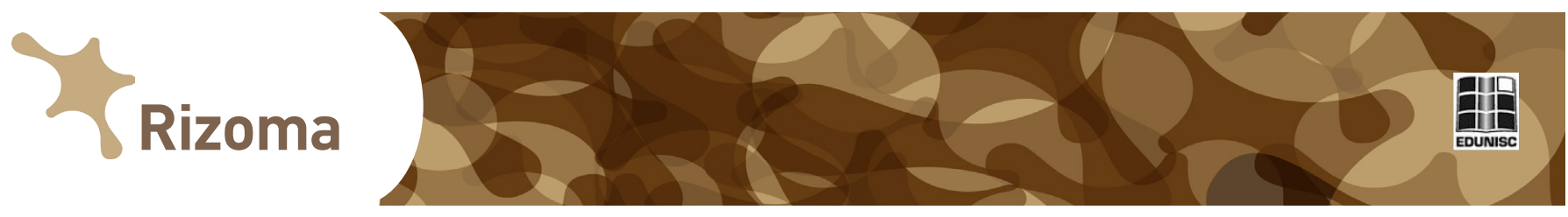

Figura 6: Chega de Fiu-fiu na FSP

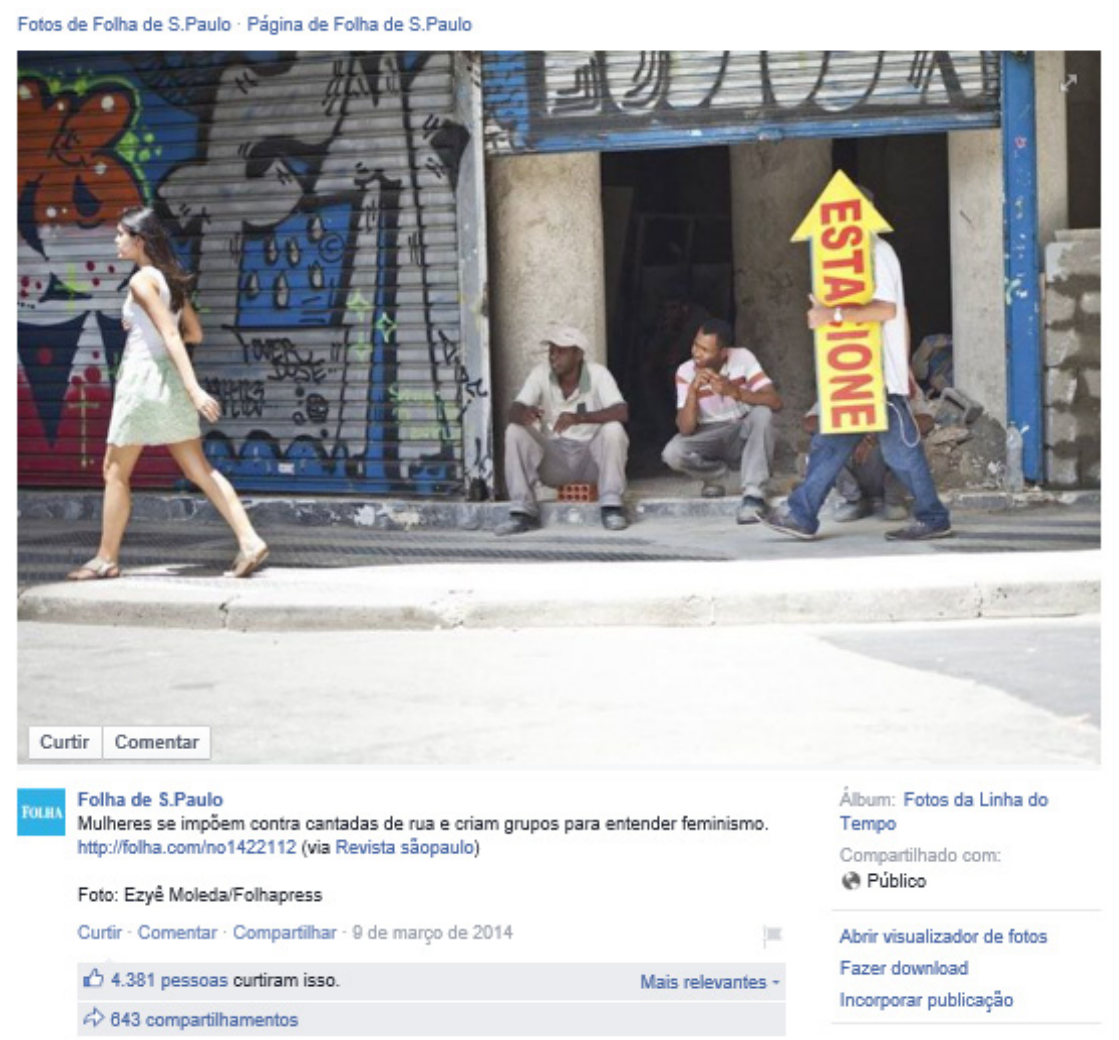

Fonte: Reprodução do Facebook da Folha de São Paulo (2015)

A publicação, apesar de ter recebido vários comentários de homens apoiando a campanha, conta com vários comentários de cunho machista, principalmente afirmando que se a cantada viesse de homens ricos seria diferente. A campanha e as feministas foram criticadas, muitos afirmaram que o fiu-fiu é algo sem importância, que não podemos dar relevância a uma campanha dessas quando em nosso país existem coisas mais sérias com que se preocupar (conforme Figura 7). 


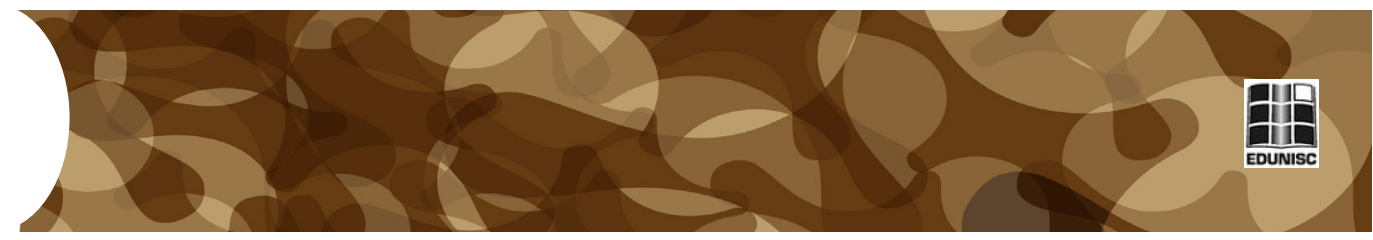

Figura 7: Exemplos de Comentários 1 (Chega De Fiu-fiu - FSP)

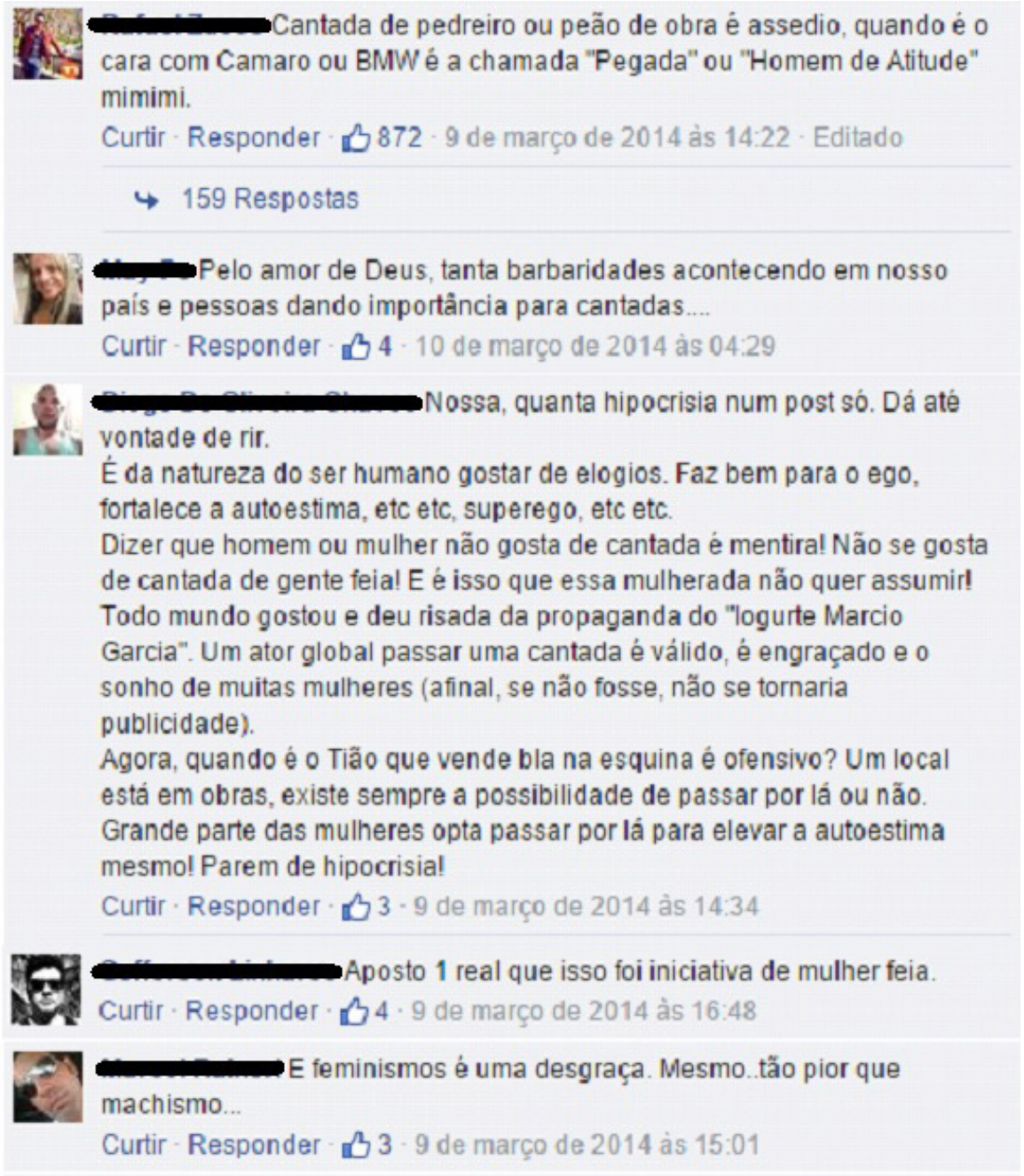

Fonte: Reprodução do Facebook da Folha de São Paulo (2015)

Ao todo foram analisados 109 comentários, sendo 50 provenientes de homens e 59 de mulheres. Dentro destes dois universos foi possível observar que $80 \%$ dos homens foram contrários à campanha e que a maioria dos comentários masculinos foram emocionais (56\%). Muitos deles também criticaram o conteúdo da campanha e o movimento feminista, conforme mostra o Gráfico 1. 


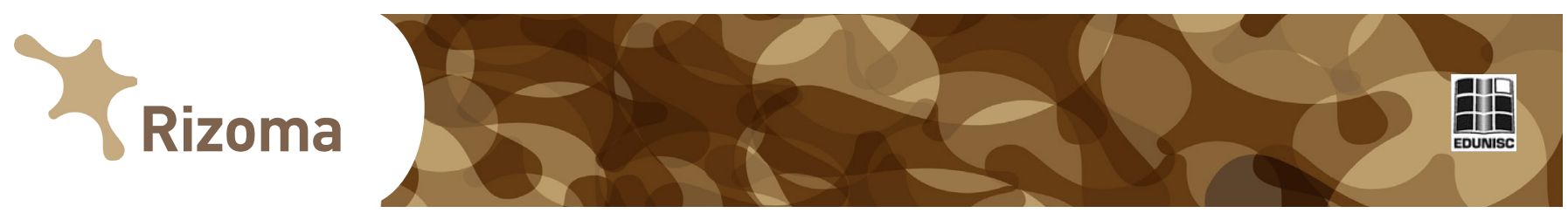

Gráfico 1: Categorização Comentários Masculinos "Chega de Fiu-fiu"

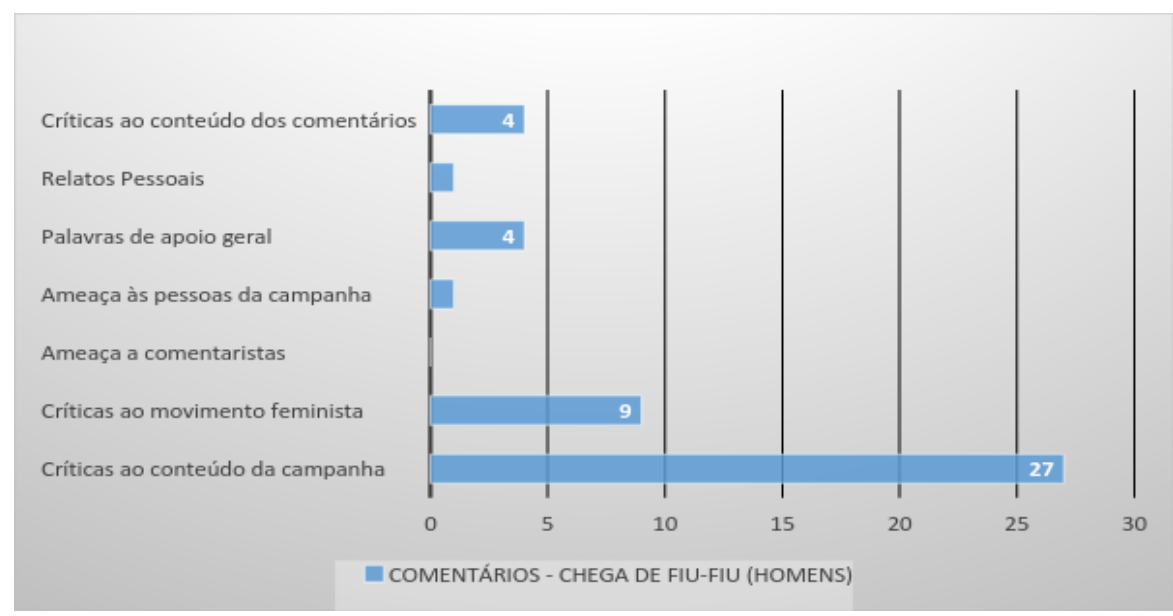

Fonte: Elaborado pelas autoras

Já as mulheres mostraram outro posicionamento: $80 \%$ são favoráveis à campanha e somente $22 \%$ delas apresentaram comentários emocionais. Várias mulheres criticaram os autores de outros comentários, muitas vezes por apresentarem argumentos de cunho machista e contrários à campanha (Gráfico 2).

Gráfico 2: Categorização Comentários Femininos "Chega de Fiu-fiu"

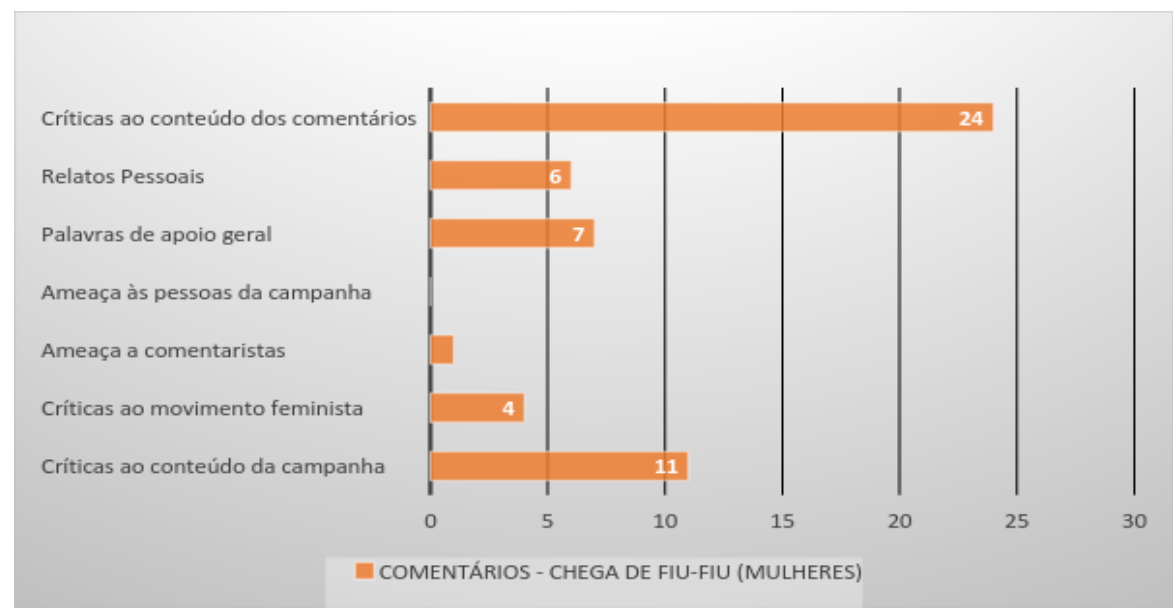

Fonte: Elaborado pelas autoras

A análise mostrou que a maioria dos comentários contrários à campanha são emocionais, ou seja, não apresentam argumentos sólidos e racionais. Apesar de a maioria dos comentários contrários serem provenientes de homens, muitas mulheres ainda não entendem a importância de campanhas como estas e da luta feminista. Ficou claro que a maioria dos comentários contrários surgiu por falta de compreensão e entendimento de alguns tópicos importantes, como a importância da luta feminista, a culpabilização da vítima e o não-reconhecimento de formas de violência de gênero que vão além da violência física, como a violência simbólica e a violência moral. 


\section{Rizoma}

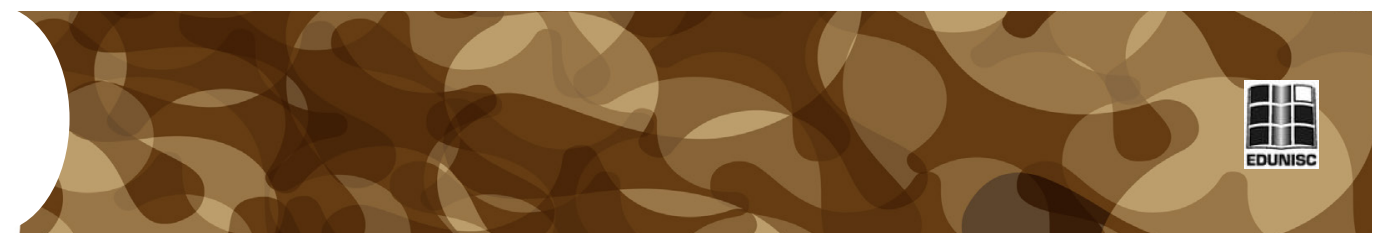

\section{2 "Eu não mereço ser estuprada" ou "Só as vadias merecem"}

Foram analisados os comentários das postagens sobre a campanha "Eu não mereço ser estuprada" nas páginas de Facebook dos portais de notícias Terra $^{10}$, Zero Hora ${ }^{11}$ e Folha de S. Paulo ${ }^{12}$. As postagens foram feitas entre

${ }^{10}$ Postagem disponível no link http://migre.me/tvBUS

${ }^{11}$ Postagem disponível no link http://migre.me/tvBXi

${ }^{12}$ Postagem disponível no link http://migre.me/tvBYz os dias 29 de março de 2014 e 31 de março do mesmo ano, período em que surgiu a campanha. Devido ao tratamento que cada portal deu a campanha e ao público de cada página, os comentários vistos em cada notícia mostraram opiniões diferentes sobre o mesmo assunto.

Na postagem do Portal Terra (Figura 8), a campanha foi apresentada com a foto de uma manifestante anônima, com explicação sobre a campanha e sobre a pesquisa que motivou o ato. A notícia chegou a mais de 43 mil curtidas, cerca de 10 mil compartilhamentos e 3 mil comentários. Desses comentários, selecionamos os 50 mais relevantes, desde que relacionados ao assunto.

Figura 8: Eu não mereço ser estuprada no Terra
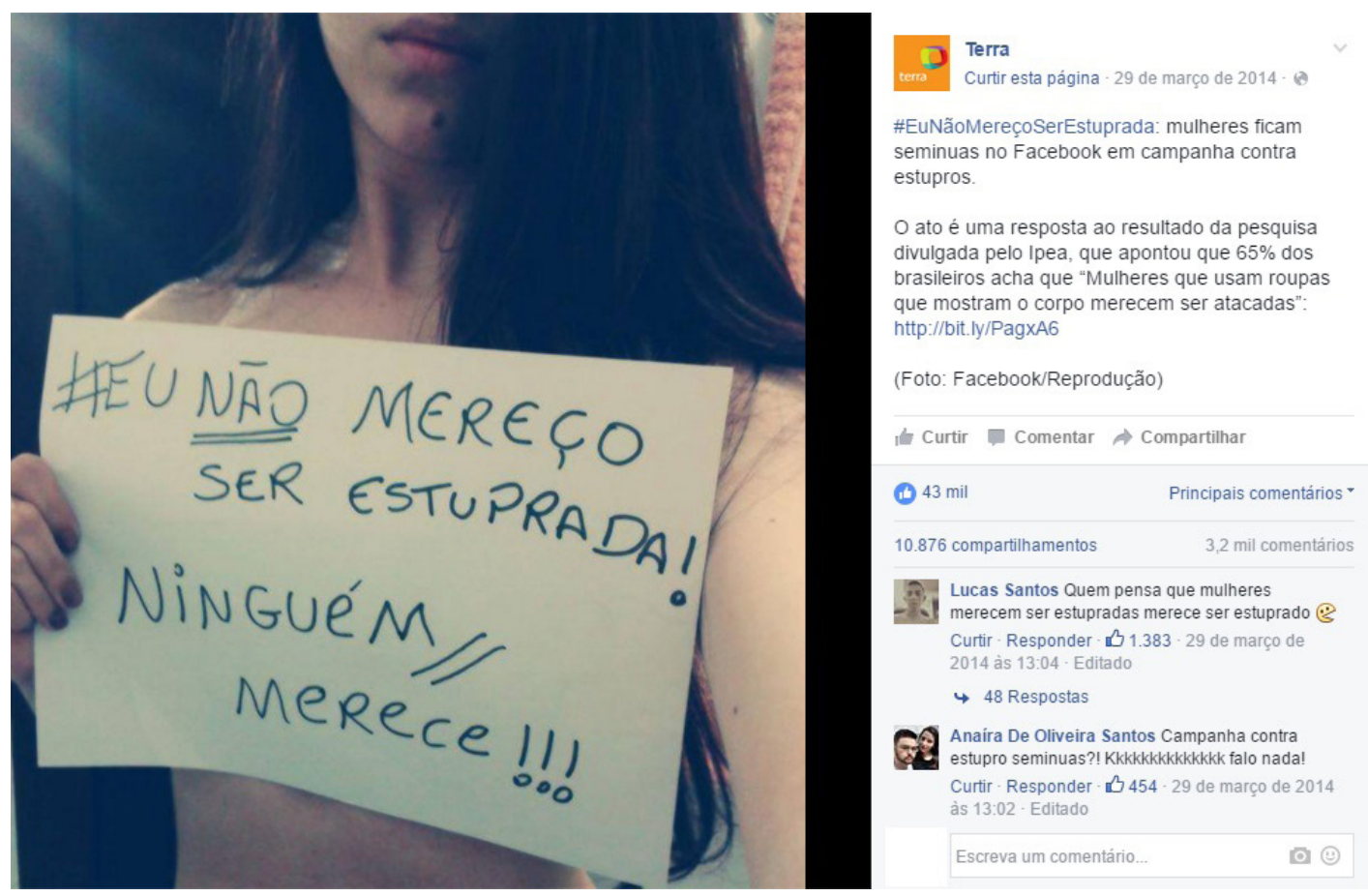

Fonte: Reprodução do Facebook do Terra Brasil (2015)

Apesar do grande apoio à campanha, uma grande parte dos comentários criticou o fato de o protesto se realizar com a utilização de fotos de mulheres seminuas. Dentre as mensagens favoráveis à campanha, muitas argumentaram dizendo que existem casos de violência sexual em países islâmicos, onde mulheres usam burcas, o que invalidaria o argumento de que usar roupa curta pode ser uma atitude causadora de estupros (conforme figura 9). 

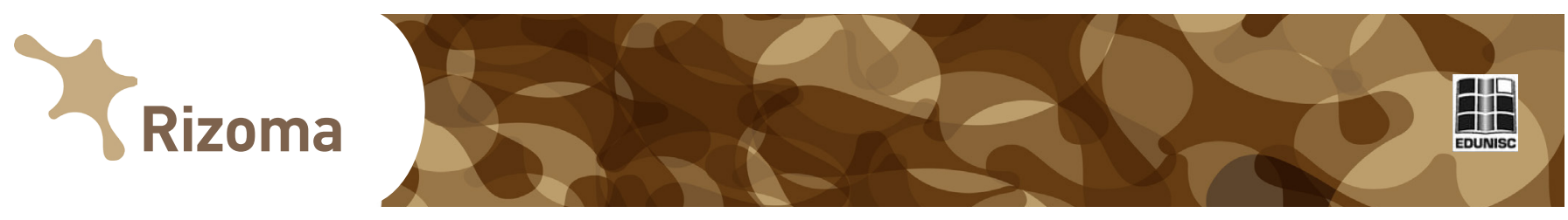

Figura 9: Exemplo de Comentários (Eu não mereço ser estuprada - Terra)

\begin{abstract}
mulheres devem se valorizar! Isso é meu ponto de vista.. não adianta nda vc sair de csa praticamente nua e querer exigir respeito sabe? o erro das mulheres hoje em dia é que as mulheres se vestem pra causar, pra atrair olhares e infelizmente, aos olhos de muitas pessoas.. isso acaba por atrair olhares ruins tbm.. influenciam em maldade.. isso nao significa tbm que só mulheres q se mostram são estrupadas, mas sim, que quando se preserva o corpo, muitas coisas podem ser evitadas.. Não adianta tira a roupa, isso é uma vergonha! Tinham mais é que tomar vergonha e se cobrir mais.. Só no Brasil que querem acabar com o estrupo ficam praticamente nuas.. MEU DEUS!

Curtir - Responder - 378 - 29 de março de 2014 às 13:16 - Editado
\end{abstract}

acontecer eu vou tirar a roupa e tirar foto com um papel na mão..." ..

Precisamos de leis mais rigidas e não de menos roupas...

Curtir - Responder - 29 - 29 de março de 2014 às 13:13

Mulheres ficam seminuas pra fazer campanha

contra estupro... Cadê a lógica??? E se não quer chamar atenção de quem não deve, não saia mostrando quase tudo de casa... simples...

Curtir - Responder - 34 - 30 de marco de 2014 às $10: 13$

Se fosse a roupa, as mulheres mulçumanas não sofreriam tanta violência sexual como sofrem!!!!! Afinal elas usam burcas, cobrem todo o corpo e mesmo assim são vítimas! Devemos educar os meninos sobre o respeito a mulher para que amanhã não sejam os estupradores

Curtir - Responder - 128 - 29 de março de 2014 às $13: 09$

se a vestimenta fosse o realmente motivo dos

estupros,países como irã,Afeganistão,iraque,em que as mulheres estão "cobertas",o índice de estupro seria zero,e não é isso que acontece...

Curtir - Responder - 48 - 29 de março de 2014 às 13:44

Fonte: Reprodução do Facebook do Terra Brasil (2015)

A postagem do Zero Hora (Figura 10), feita no dia 31 de março de 2014, mostrou as fotos das artistas Daniela Mercury e Valesca Popozuda, que aderiram à campanha. A notícia teve 6 mil curtidas, mais de 1300 compartilhamentos e cerca de 375 comentários.

Figura 10: Eu não mereço ser estuprada no Zero Hora
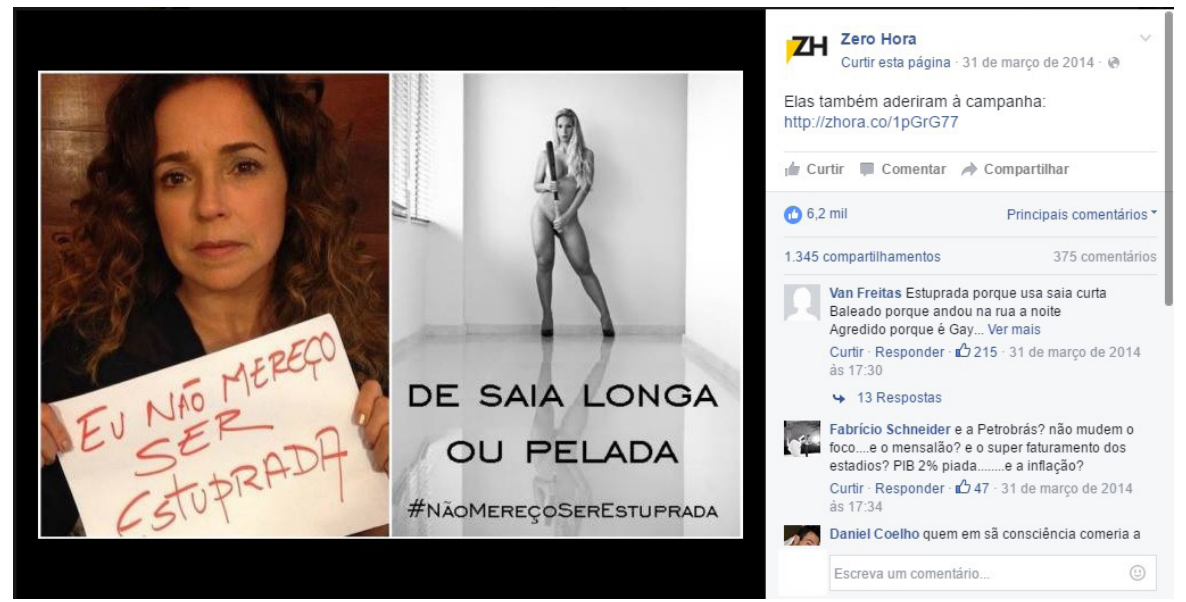

Fonte: Reprodução do Facebook da Zero Hora (2015) 

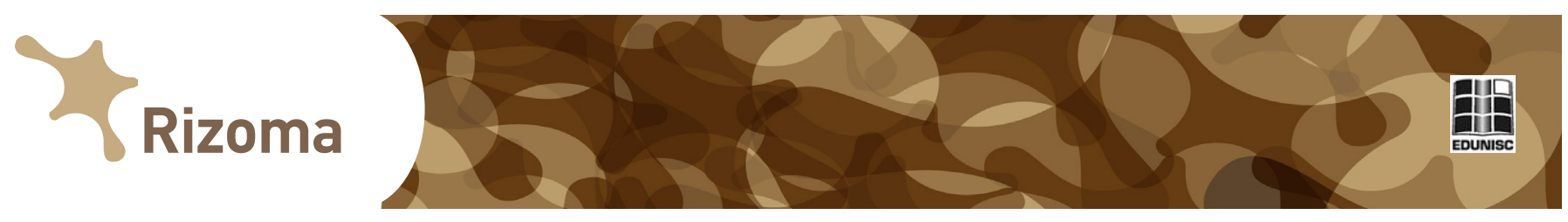

Uma grande quantidade de comentários menosprezava a importância da campanha e dizia que existem assuntos mais relevantes para se noticiar. Além de criticar o conteúdo da campanha, muitos comentários reclamaram das apoiadoras e as chamaram de "oportunistas que só queriam chamar atenção". De acordo com algumas pessoas, elas se vendem para as revistas com frequência e, portanto, não podem reclamar de nada. $\mathrm{O}$ fato de elas protestarem sem roupa também foi alvo de críticas, com o argumento de que as mulheres precisam "se dar ao respeito" (Figura 11).

Figura 11: Exemplos de Comentários (Eu não mereço ser estuprada - Zero Hora)

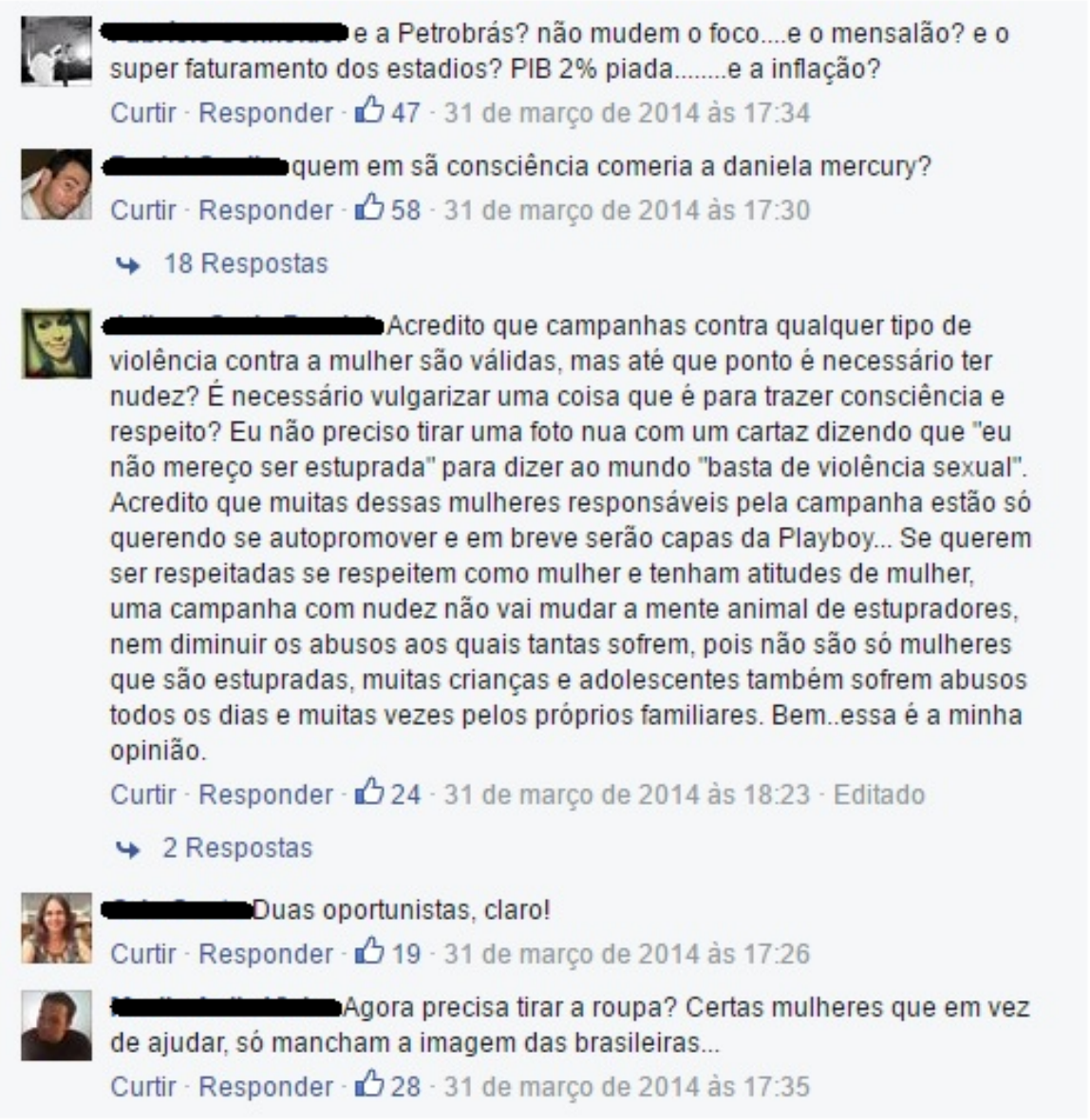

\section{Fonte: Reprodução do Facebook da Zero Hora (2015)}

A postagem da Folha de S. Paulo (Figura 12), feita no dia 29 de março de 2014, usou a foto de uma leitora, chamada Bianca Medeiros, para ilustrar a notícia. Na postagem, além de explicar o teor da campanha, a página se posicionou dizendo que "Nenhuma mulher merece". A notícia teve 231 mil curtidas, 18 mil comentários e mais de 53 mil compartilhamentos. 

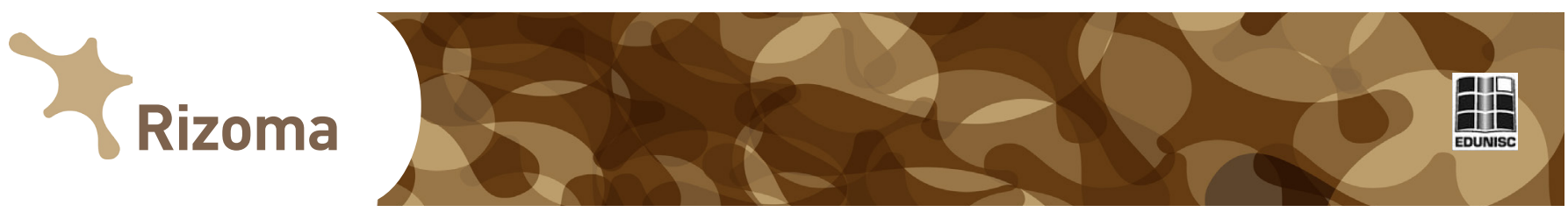

Figura 12: Eu não mereço ser estuprada na FSP

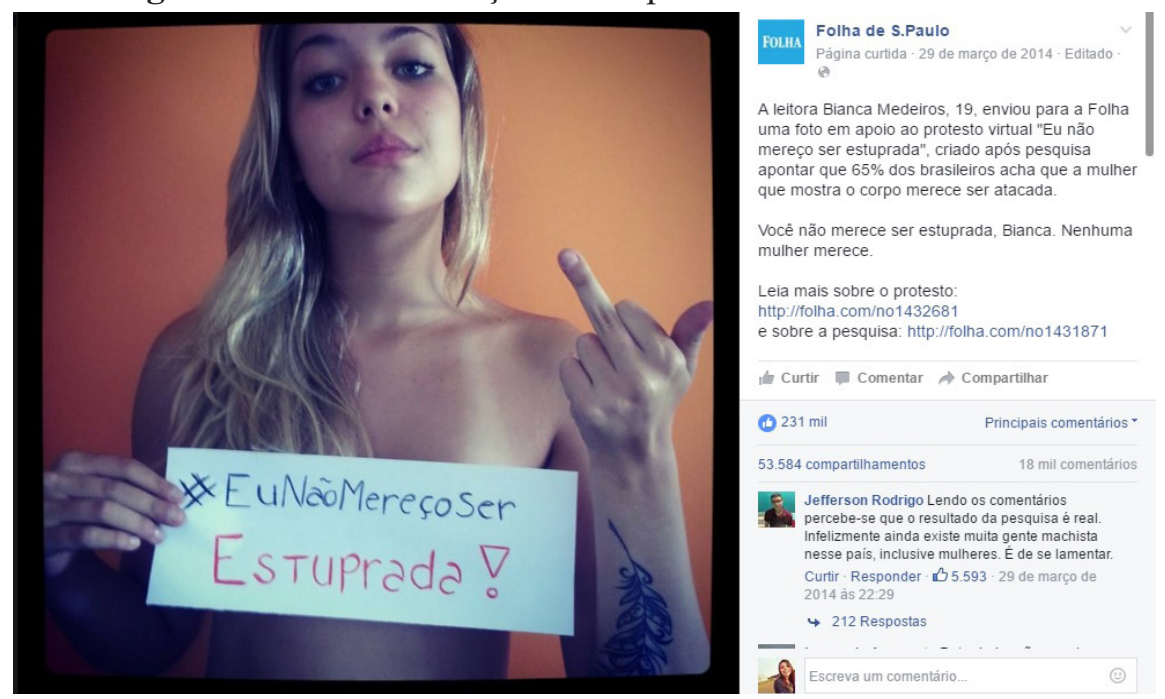

Fonte: Reprodução do Facebook da Folha de São Paulo (2015)

A maioria do público que postou comentários pareceu compreender a importância do assunto e se colocou a favor de uma campanha contra o estupro. Muitos também ficaram chocados com o teor da pesquisa divulgada e se colocaram contra outros comentários machistas.

Um ponto recorrente mesmo entre aqueles que demonstravam apoio ao protesto foi o fato de as manifestantes estarem seminuas, o que segundo alguns era desnecessário e, de acordo com outros, incoerente. Entre aqueles que se posicionavam abertamente contra a campanha, a maioria explicava que usar pouca roupa poderia ser um desencadeador de atos como estupros ou assédios. Houve também quem deslegitimasse a relevância do problema, dizendo que as meninas que participaram da ação só queriam aparecer na mídia (conforme Figura 13).

Figura 13: Exemplos de comentários (Eu não mereço ser estuprada - FSP)

Eu acho o seguinte. Da mesma forma que não se deve andar em lugares perigosos, exibindo objetos caros e de marca, evitandose, com isso, assaltos e sequestros, as mulheres precisam tomar cuidado com a maneira como se expõem em determinados lugares. Assim como existem assaltantes e bandidos, existem estupradores. Não acho que mulheres que se vestem com roupas curtas e chamativas merecem ser estupradas, isso jamais. Mas é fato que ficam mais expostas a esse tipo de crime.

Curtir - Responder - 3574 - 29 de março de 2014 às $22: 55$

Acho engraçado que muitos dos comentários aqui são de mulheres ridicularizando 0 ato da moça estar tampando os seios com um cartaz! Por que a mulher tem que se vestir para ser valorizada? Por que uma mulher que mostra os seios (tampados) é falta de res... Ver mais

Curtir - Responder - 347 - 31 de março de 2014 às 20:21 - Editado

Mais uma querendo mídia....

Curtir - Responder - 13832 - 29 de março de 2014 às 22:25

Fonte: Reprodução do Facebook da Folha de São Paulo (2015) 

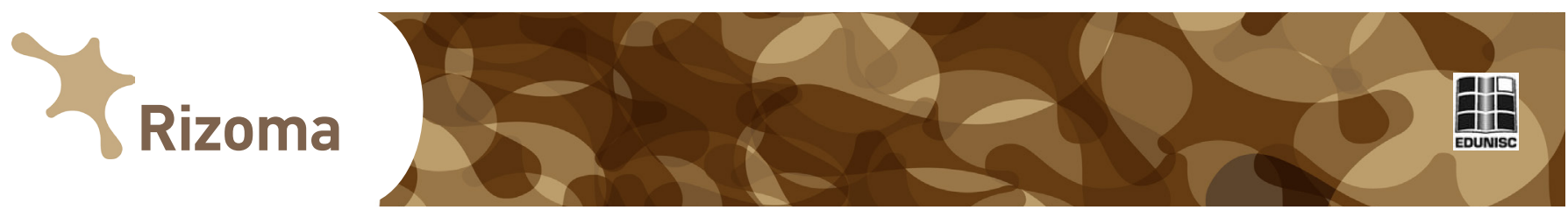

Foram analisados 147 comentários, com $56 \%$ de comentários vindos de mulheres e $44 \%$ de homens. Dos homens, $62 \%$ se posicionaram a favor da campanha e usaram argumentos em seus comentários, sendo assim, considerados racionais. Em relação ao conteúdo, houve bastante crítica aos comentários, por parte dos que eram favoráveis ao protesto. Já entre o público contrário, boa parte criticou o movimento feminista e o conteúdo da campanha, conforme Gráfico 3.

Gráfico 3: Categorização de comentários masculinos - Eu não mereço ser estuprada

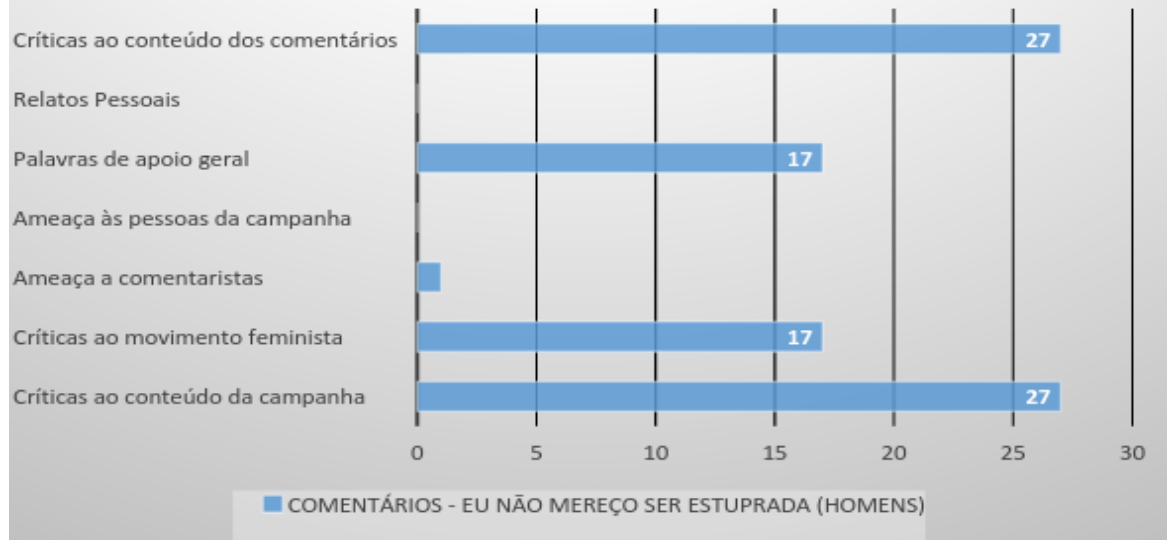

Fonte: Elaborado pelas autoras

Entre as mulheres, a maioria também postou mensagens favoráveis a campanha, totalizando $82 \%$, e somente $20 \%$ dos comentários foram emocionais. Do total, 58 comentários criticaram o conteúdo dos demais comentários, conforme Gráfico 4.

Gráfico 4: Categorização de comentários femininos - Eu não mereço ser estuprada

\section{COMENTÁRIOS - EU NÃO MEREÇO SER ESTUPRADA (MULHERES)}

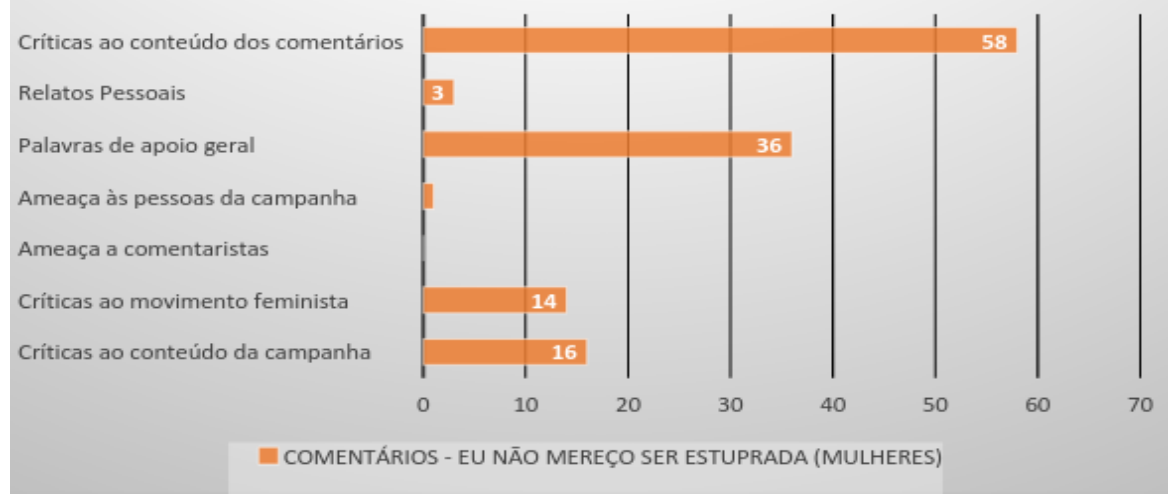

Fonte: Elaborado pelas autoras 

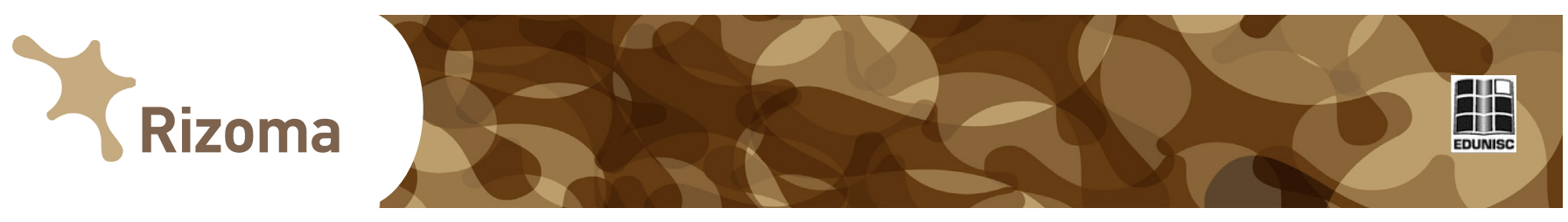

No geral, as críticas ao conteúdo da campanha são provenientes tanto de homens quanto de mulheres. Grande parte das dúvidas apresentadas é relacionada a conceitos básicos do feminismo como: toda mulher tem liberdade para usar a roupa que quiser; a culpa nunca é da vítima; mulheres não devem sofrer assédio como resposta a determinado comportamento.

\section{Considerações finais}

Compreendemos que o feminismo não é um movimento único e homogêneo, sendo mais correto falar em movimentos feministas. Isso significa que grupos ativistas feministas continuam atuando de maneira tradicional, principalmente através de manifestações de rua, como é o caso da Marcha das Vadias e da Marcha Mundial da Mulheres. Todavia, mesmo esses grupos que não abandonaram suas formas originais de protesto, mas especialmente mulheres sem conexão com movimentos formais, ao não terem suas demandas - feministas - exploradas pelos meios de comunicação tradicionais, buscaram na internet um espaço para debates e disseminação de ideias, transformando sua maneira de fazer ativismo.

Em 2015, várias campanhas feministas viralizaram nas redes sociais, entre elas as duas campanhas analisadas neste artigo. Essas campanhas, juntamente com fanpages e blogs feministas de grande alcance, são responsáveis pelo aumento do interesse em relação ao feminismo, conforme mostrou a pesquisa realizada pelo Think Olga, citada na introdução deste artigo, que demonstrou um aumento de $1100 \%$ nas pesquisas com o termo "feminismo" no Google, em pouco mais de um ano. $\mathrm{O}$ ativismo feminista na internet também é parte responsável pela disseminação do feminismo especialmente entre as jovens, que se mostram mais receptivas ao feminismo e muitas vezes se reconhecem e se apresentam como feministas.

Entretanto, é frequente que mulheres que alcançaram visibilidade devido ao ativismo feminista sejam ameaçadas e enfrentem agressões diárias devido ao seu posicionamento. Por essas razões, este artigo teve como objetivo verificar a repercussão entre os internautas das duas campanhas citadas. Os resultados mostraram que as mulheres comentam com mais frequência e com maior tendência à racionalidade, uma vez que cerca de $80 \%$ dos seus comentários (considerando as duas campanhas) vêm acompanhados de argumentação. A maioria das mulheres aprovou o conteúdo das campanhas, enquanto somente $20 \%$ dos homens foram favoráveis à campanha "Chega de Fiu-fiu", número que subiu para $62 \%$ na campanha "Eu não mereço ser estuprada". Entre os comentários favoráveis às campanhas, é mais frequente que critiquem o conteúdo de outros comentários, enquanto entre os comentários contrários é mais frequente que critiquem o conteúdo da campanha do que o movimento feminista como um todo. As críticas pessoais apareceram em um número muito pequeno dos comentários. 

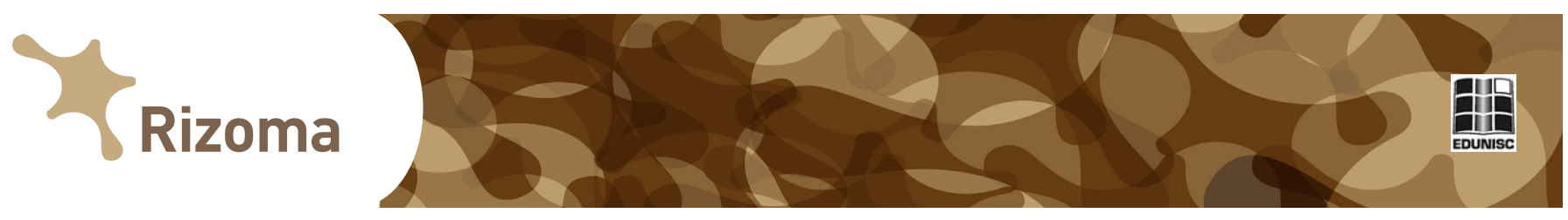

Como visto, a internet é uma importante ferramenta de divulgação dos movimentos sociais. Porém, a maneira como as demandas desses movimentos são apresentadas tem um alto potencial de rejeição neste ambiente. O Facebook parece ser mais eficaz na "pregação para convertidos" do que para propagar as demandas do movimento para um público mais extenso. $\mathrm{Na}$ análise dos comentários aqui realizada foi possível perceber que os indivíduos já possuem uma posição bem delimitada: são feministas ou são contrários ao feminismo. Por isso, a discussão realizada nos comentários se mostra pouco profícua ao considerarmos os moldes da deliberação pública. Assim, acreditamos que para que a comunicação dos movimentos sociais seja mais assertiva é necessário um trabalho continuado, que agregue a comunicação online a ações offline de formação e disseminação de suas demandas. Os movimentos não podem prescindir, ainda, do apoio dos meios de comunicação tradicionais, fundamentais para a disseminação de suas causas para um público mais abrangente. Da mesma maneira, o apoio de personalidades é fundamental para o sucesso destas campanhas, uma vez que transfere prestígio às causas em debate e gera uma sensibilização imediata de seus fãs.

\section{Referências}

ABDALLA, M. M.; BRAVO, I. G. "Eu odeio Coca-Cola": uma análise etnográfica sobre o discurso antimarca da comunidade virtual do Orkut. Revista Estratégia \& Negócios, v. 4, n. 2, p. 61-86, jun./dez. 2011.

HABERMAS, Jurgen. The theory of communicative action: Reason and rationalization of society (T. McCarthy, Trans. Vol. 1). Boston, MA: Beacon Press, 1984.

HENRIQUES, Márcio Simeone. Ativismo, movimentos sociais e Relações Públicas. In: KUNSCH, M..; KUNSCH, W. L. (org). Relações Públicas Comunitárias: a comunicação em uma perspectiva dialógica e transformadora. São Paulo: Summus, 2007.

LEMOS, André. Olhares sobre a Cibercultura. Porto Alegre: Sulina, 2003.

MORAES, Dênis de. Comunicação virtual e cidadania: movimentos sociais e políticos na Internet. Revista Brasileira de Ciências da Comunicação, v. 23, n. 2, julho/dezembro de 2000.

PARAIZO, Danúbia. Blogs conquistam espaço ao dar voz às "esquecidas" pela grande mídia. Portal Imprensa, 2015.

PEREIRA, Marcus Abílio. Internet e mobilização política - os movimentos 


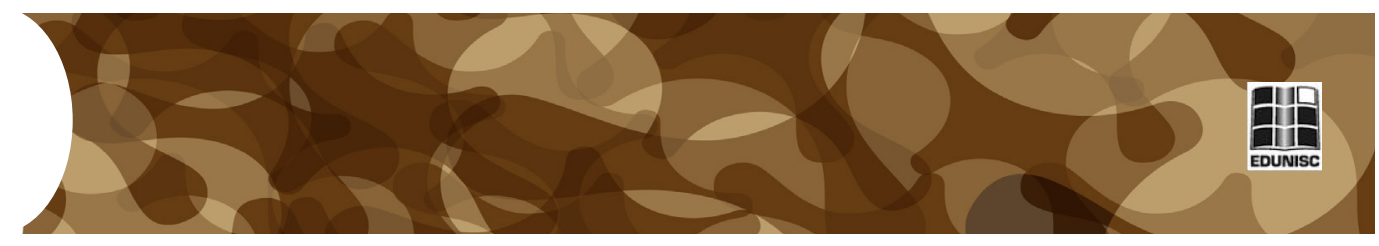

sociais na era digital. ENCONTRO DA ASSOCIAÇÃO BRASILEIRA DE PESQUISADORES EM COMUNICAÇÃO E POLÍTICA, 4, 2011, Rio de Janeiro. Anais... Rio de Janeiro: Universidade do Estado do Rio de Janeiro, 2011.p. $1-4$.

VIEIRA, Vera de Fatima. Comunicação e feminismo: as possibilidades da era digital. 2012. 234f. Tese (Doutorado em Comunicação) - Escola de Comunicação e Artes, Universidade de São Paulo. São Paulo, 2012. 